NBER WORKING PAPER SERIES

\title{
HIRING CHEERLEADERS: BOARD APPOINTMENTS OF "INDEPENDENT" DIRECTORS
}

\author{
Lauren Cohen \\ Andrea Frazzini \\ Christopher Malloy \\ Working Paper 14232 \\ http://www.nber.org/papers/w14232
}

\author{
NATIONAL BUREAU OF ECONOMIC RESEARCH \\ 1050 Massachusetts Avenue \\ Cambridge, MA 02138 \\ August 2008
}

We would like to thank Joakim Bang, Brad Barber, Nick Barberis, Sugato Bhattacharya, John Campbell, Josh Coval, Simon Gervais, Gustavo Grullon, Kathleen Hanley, Ayla Kayhan, Bruce Kraus, Alexander Ljunqqvist, Ulrike Malmendier, Jennifer Marietta-Westberg, Cade Massey, Matt Spiegel, Erik Stafford, Jeremy Stein, Jake Thomas, Steen Thomsen, Sheridan Titman, Lori Walsh, and seminar participants at Emory, Harvard Business School, Helsinki School of Economics, Northeastern University, Oxford University, University of Melbourne, University of New South Wales, the Texas Finance Festival, the Yale SOM Behavioral Sciences Conference, the American Finance Association (AFA) meetings, the European Finance Association (EFA) meetings, the Singapore International Conference on Finance, the Families, Networks, and Firms Conference at Thammasat Business School, and the United States Securities and Exchange Commission (SEC) for helpful comments. We also thank Alex Tang for excellent research assistance. In addition, we are grateful to BoardEx and Linda Cechova for providing firm board data. We also thank Alex Tang for excellent research assistance. In addition, we are grateful to BoardEx and Linda Cechova for providing firm board data. The views expressed herein are those of the author(s) and do not necessarily reflect the views of the National Bureau of Economic Research.

NBER working papers are circulated for discussion and comment purposes. They have not been peerreviewed or been subject to the review by the NBER Board of Directors that accompanies official NBER publications.

(C) 2008 by Lauren Cohen, Andrea Frazzini, and Christopher Malloy. All rights reserved. Short sections of text, not to exceed two paragraphs, may be quoted without explicit permission provided that full credit, including $\odot$ notice, is given to the source. 
Hiring Cheerleaders: Board Appointments of "Independent" Directors

Lauren Cohen, Andrea Frazzini, and Christopher Malloy

NBER Working Paper No. 14232

August 2008, Revised April 2010

JEL No. G28,G34,J24,J44

\begin{abstract} board appointments.

Lauren Cohen

Harvard Business School

Baker Library 273

Soldiers Field

Boston, MA 02163

and NBER

lcohen@hbs.edu

Andrea Frazzini

AQR Capital Management, LLC

Two Greenwich Plaza, 3rd Floor

Greenwich, CT 06830

andrea.frazzini@aqr.com

Christopher Malloy

Harvard Business School

Baker Library 277

Boston, MA 02163

cmalloy@hbs.edu
\end{abstract}

We provide evidence that firms appoint independent directors who are overly sympathetic to management, while still technically independent according to regulatory definitions. We explore a subset of independent directors for whom we have detailed, micro-level data on their views regarding the firm prior to being appointed to the board: sell-side analysts who are subsequently appointed to the board of companies they previously covered. We find that boards appoint overly optimistic analysts who are also poor relative performers. The magnitude of the optimistic bias is large: $82.0 \%$ of appointed recommendations are strong-buy/buy recommendations, compared to $56.9 \%$ for all other analyst recommendations. We find that appointed analysts' optimism is stronger at precisely those times when firms' benefits are larger, and that appointing firms increase earnings management, and perform poorly, following these 
What makes a good monitor? Embodied in recent regulatory requirements is the notion that independent directors provide a particular type of objective, shareholder-minded monitoring. ${ }^{1}$ At the same time, little is known about the characteristics of independent directors, or the factors that influence the selection process of these directors. It seems almost necessary that a senior officer or board member has some relationship with, or prior knowledge of, a potential independent director in order to ensure they have enough information to be able to recommend the member for board election. This reality need not be problematic, as although it could be that this relationship skews the view of these "independent" directors, it could also reduce information asymmetries regarding the potential value of the director for the given board. ${ }^{2}$

In this paper we exploit a unique, hand-collected database of independent directors to test the hypothesis that boards appoint directors who, while technically independent according to regulatory definitions, nonetheless may be overly sympathetic to management. To do so we investigate a subset of independent directors for whom we have detailed, micro-level data on their views regarding the firm prior to being appointed to the board. We use these track records to compare the roles of optimism (i.e., hiring a cheerleader for management) versus skill (i.e., hiring an objective and able observer) in the board appointment process. Focusing on ex-ante, observable characteristics of the independent directors themselves allows us to directly evaluate the objectivity and potential efficacy of independent directors based solely on their actual opinions about the firm in question.

The agents we examine are former sell-side analysts who end up serving on the board of companies they previously covered. Motivating our empirical strategy is the fact that $91 \%$ of the board members of the appointing firms in our sample are on the

\footnotetext{
${ }^{1}$ See, for example, the SEC's press release on November 4, 2003, in which the SEC approved new rules proposed and adopted by the New York Stock Exchange and the Nasdaq Stock Market requiring widespread strengthening of corporate governance standards for listed companies. The new rules "establish a stricter, more detailed definition of independence for directors and require the majority of members on listed companies' boards to satisfy that standard...Pursuant to NYSE Section 303A(2) of the NYSE Manual, no director would qualify as "independent" unless the board affirmatively determines that the director has no material relationship with the company (either directly or as a partner, shareholder or officer of an organization that has a relationship with the company)." See http://www.sec.gov/rules/sro/34-48745.htm for more details. See also Duchin et al. (2008) for a review of recent changes to the regulatory requirements for corporate boards.

${ }^{2}$ See Adams and Ferreira (2007) for a discussion of the tradeoffs involved in board construction.
} 
board both at the time the analyst was covering the firm and at the time of the subsequent board appointment, suggesting that the firm-analyst relationships we explore exhibit a great deal of continuity. Further, unlike former CEOs or other senior executives who serve on corporate boards, for whom past performance attribution is complicated by the fact that firm performance is difficult to disentangle from individual performance, sell-side analysts' opinions and performance can be easily assessed. We can explicitly compute measures of skill/ability and optimism by examining the composition and stock return performance of analysts' buy/sell recommendations. In doing so we find evidence that boards appoint overly optimistic analysts who are also poor relative performers.

In particular, board-appointed analysts issue significantly more positive recommendations on companies that subsequently appoint them to the board; both relative to the other stocks they cover, and relative to other analysts covering these same stocks. The magnitude of this result is large: $82.0 \%$ of these recommendations are strong-buy or buy recommendations, compared to $56.9 \%$ for all other analyst recommendations (an over 25\% difference). In regressions of recommendation levels (1=Strong Sell, 5=Strong Buy) on an appointment dummy (equal to 1 if the analyst recommending the given stock is subsequently appointed to the board of directors of that firm), the coefficient on appointment implies an increase in favorableness of rating from between a Hold and a Buy for the average recommendation to between a Buy and Strong Buy for appointed recommendations. This result is nearly three times as large as the optimism effect associated with affiliation (here a dummy variable equal to 1 if the given firm has an underwriting relationship with the analyst's brokerage house), which is the subject of a vast analyst literature (see, for example, Lin and McNichols (1998), Lin et al. (2005), Michaely and Womack (1999), Hong and Kubik (2003)).

Additionally, we find that board-appointed analysts exhibit poor relative performance on their stock recommendations on appointing firms. For example, we find that appointed analysts issue 60-90\% more directionally incorrect calls on stock recommendations for firms that appoint them compared to the typical analyst recommendation. Also, while the typical analyst upgrade earns a significant $9.4 \%$ in the year following the upgrade, upgrades by appointed analysts on appointing firms earn 
only an insignificant 3.6\%. Finally, we show that appointed analysts demonstrate inferior overall forecasting ability, both for earnings forecasts and for stock recommendations, across the entire portfolio of stocks they cover. Thus, while it is true that an optimistic analyst may simply be more likely to accept a board seat than an otherwise similar analyst, our results imply that firms are either appointing the wrong analysts, or that firms should simply demand zero analysts if the only willing supply consists of biased and poor performing analysts.

To get a richer understanding of the behavior of board-appointed analysts, we also explore the dynamics of optimism in our sample. In doing so we find that appointed analysts' optimism is stronger: a) when firms have high short interest, b) before times of increased stock issuance by the firm, and c) when the last recommendation issued on the firm was a downgrade. All of these instances are times when a manager would most welcome good news on his stock. Further, we find no evidence of optimism in the earnings forecasts of appointed analysts, which helps to rule out the possibility that appointed analysts are simply uniformly optimistic about all prospects of the appointing firm, in contrast to a specific pattern of recommendations that benefits the managers of the firm (i.e., sympathetic to management). We provide additional evidence on this distinction between being optimistic versus being sympathetic towards management when we demonstrate below that CEO compensation increases post-analyst-appointment.

Of course, appointing overly bullish analysts need not imply bad monitoring. It is possible that optimistic directors might facilitate productive cooperation and communication among board members, or have ideas on new strategies and directions for growth. To explore these issues, we examine the behavior and performance of appointing firms after these appointments. We find that appointing firms engage in increased questionable behavior after the appointment of these analysts: appointing firms significantly increase their earnings management behavior, reporting higher discretionary accruals post-appointment relative to the pre-appointment period. Finally, the post-appointment performance of these firms is poor: a calendar-time portfolio of appointing stocks underperforms a portfolio of non-appointing stocks by $1.3-2.0 \%$ per month in the year after these appointments. 
To overcome the potential endogeneity of analyst board appointments, we instrument for the appointment of a cheerleader analyst by exploiting the post-Global Settlement time period when analysts were widely scrutinized and scorned and hence in low demand to serve as potential directors. We use this exogenous shock to the desirability/availability of analysts in the pool of potential directors as an instrument for the actual appointment of cheerleader analysts. We first show that Global Settlement did have a significant negative impact on the appointment of analysts to boards of directors (first-stage). We then find that the instrumented-appointment of analysts to the board led to a large and significant increase in earnings management post-(instrumented)-appointment. We also examine CEO compensation in this IV framework, and find that appointing firms significantly increase CEO compensation post-appointment of a cheerleader analyst, suggesting that appointing firms' boards are sympathetic to management post-appointment, despite the poor subsequent stock return performance.

Overall, our findings provide new evidence on the board selection process, and on the characteristics of independent directors. Our unique micro-level data on analyst board appointments enables us to investigate the track records of a subset of independent directors in a clean and direct way in order to investigate their optimism and expertise with respect to the appointing firms. To our knowledge, although papers have used measures of director relationships, this paper is the first to empirically document this phenomenon of firms actively appointing board "cheerleaders" (i.e., board members who have an empirically documented optimistic view of the firm/management, but who possess little skill in assessing the firm or its prospects, suggesting them to be unsuitable monitors). Since these cheerleaders are of course technically labeled as independent directors, our findings call into question the idea that increasing the representation of independent directors on the board is by definition a positive step.

Additionally, our results on the behavior and ultimate performance of the appointing firms suggest that exploring the past track records and backgrounds of board members is a useful way to identify cross-sectional variation in firm governance quality. Although we focus on subset of board appointments in this paper, we believe our results 
help shed light on independent directorships in general. Even in this pool of former sell side analysts of the firm, who are potentially very informed and skilled monitors, firms either seem to be demanding (or at the very least settling) for overly optimistic analysts who are poor relative performers. Collectively our results suggest that the board appointment process involving other classes of independent directors, where the same potential monitoring skill might not be present, could be even more problematic.

The remainder of the paper is organized as follows. Section I provides background and motivation. Section II describes the data. Section III reports our results on the positive bias in the recommendations of board-appointed analysts. Section IV documents the relative underperformance of appointed analysts. Section V explores the dynamics of appointed analysts' recommendations. Section VI examines the post-appointment behavior and performance of appointing firms, including the IV estimation for board appointments. Section VII discusses the distinction between optimism in general versus sympathy towards management, as well as the interplay between the supply and demand for biased analysts. Section VIII concludes.

\section{Background and Motivation}

Our data and approach allow us to investigate the micro foundations of several competing views on how boards function. Specifically, by looking at observable measures of the optimism and ability of a subset of board appointees, we can directly test the hypothesis that boards engage in a type of "window-dressing" when appointing independent directors. This view, embraced by many skeptics of recent regulatory reforms and articulated by Romano (2005), maintains that setting numerical targets for independent directors will not improve corporate governance (nor have any effect on firm performance) because managers can still appoint directors who are independent according to regulatory definitions, but nonetheless still overly sympathetic to management.

A competing viewpoint, which forms the foundation of recent regulatory changes (including the Sarbanes-Oxley Act of 2002 (SOX), as well as rules enacted by the Securities and Exchange Commission (SEC), New York Stock Exchange (NYSE), and National Association of Securities Dealers (NASD)), argues that independent directors 
are objective, shareholder-focused monitors of management, and therefore that increasing their representation on boards should uniformly improve corporate governance. Independent directors, under this view, are custodians of shareholder interests, whose presence on the board help reduce agency problems and improve firm performance.

Yet another hypothesis suggests that boards are optimally constructed so as to maximize shareholder value, such that any mandated increases in board independence will likely hurt firm performance. Not surprisingly, since all three of these theories have predictions on how changes in board independence may affect future performance, the typical approach in the literature to evaluating these stories has been to relate measures of board independence (e.g., increases in the percentage of independent directors on a board) to future performance of the firm. The problem with this strategy is that board composition is endogenous, so identifying a link between board independence and firm performance is difficult (even if one exists) if poor performance causes an increase in board independence (as in Hermalin and Weisbach (1998)), or if other factors cause comovement in board composition and firm performance (as in Harris and Raviv (2007)). Recent theory also suggests that board independence is unlikely to have a uniform effect across firms, and that the effectiveness of independent directors may depend on the information environment of the firm (see Hermalin and Weisbach (1998), Raheja (2005), Adams and Ferreira (2007), and Harris and Raviv (2007)). ${ }^{3}$

Perhaps as a result of these issues, many studies fail to find a strong relation between board independence and firm performance (see, for example, Bhagat and Black (2002), Hermalin and Weisbach (2003), Fields and Keys (2003)). However, more recent studies (see, for example, Dahya and McConnell (2007) and Duchin et al. (2008)) identify exogenous changes in board structure by exploiting shifts in regulatory environments and provide evidence that increases in board independence precede improvements in firm performance. In particular, Duchin et al. (2008) find that the effect of outside directors on firm performance is small on average; however, consistent

\footnotetext{
${ }^{3}$ Note that incorporating information considerations into evaluations of board composition builds off a long-understood notion (see Berle and Means (1932), Fama and Jensen (1983), Jensen (1993)) that the effectiveness of outside directors may be limited by their inferior information relative to corporate insiders.
} 
with the recent theory above, the effect of outside directors on firm performance varies according to the information environment of a firm: outside directors are effective when the cost of acquiring information about a firm is low, but ineffective when the cost of acquiring information is high.

The paper most closely related to ours is perhaps Brickley et al. (1999), who investigate a sample of former CEOs who end up on boards of companies after they retire as CEOs. ${ }^{4}$ Their focus is on the managerial incentives that these possible future board appointments provide for CEOs during their tenures, but they do provide evidence that boards may consider ability and merit when selecting directors by showing that the likelihood of post-retirement board service by a CEO is positively related to the stock market performance of that CEO's firm during her tenure. ${ }^{5}$ The problem of course with using CEOs and senior executives is that past performance attribution is complicated by the fact that firm performance is difficult to disentangle from individual performance. $^{6}$ In addition, in the majority of past CEO appointments (outside CEOs onto the board of another firm), one cannot calculate skill of the CEOs with respect to the exact firm they subsequently serve on the board of, making it more difficult to assess their suitability for the appointing firm in particular. By contrast, our focus on sell-side analysts alleviates this issue, since we can explicitly compute measures of skill/ability and optimism for each analyst with respect to the appointing firm (and with respect to her entire portfolio); in doing so, we can directly test the true track record and implicit firm motivation for our sample of appointed independent directors.

\section{Data}

The data in this study are collected from several sources. We obtain biographical information and past employment history for directors and senior company officers from

\footnotetext{
${ }^{4}$ See also Lee (2007) for more recent evidence on post-retirement board service by former CEOs. In addition to this work, Stern and Westphal (2006) use survey evidence to find that managers who engage in ingratiatory behavior toward CEOs are more likely to receive appointments on boards with the CEO.

${ }^{5}$ See also Kaplan and Reishaus (1990) and Gilson (1990), as well as a body of empirical research (summarized in Yermack (2006)) that argues that what matters for firm performance are the qualifications of outside directors, such as financial expertise (DeFond et al. (2005)), business knowledge and experience (Fich (2005)), and the time commitments of outside directors (Fich and Shivdasani (2006)).

${ }^{6}$ See Bertrand and Schoar (2003).
}

Hiring Cheerleaders - Page 7 
Boardex of Management Diagnostics Limited. The Boardex data contain relational links among boards of directors and other corporate officials. Links in the dataset are constructed by cross-referencing employment history, educational background and professional qualifications. For each firm, we use the link file to reconstruct the annual time series of identities of board members and senior officers of the firms.

We use analysts' stock recommendation data from the I/B/E/S historical recommendation detail file, which codes recommendations on a common scale from 1 to 5, where 1=Strong Buy, 2=Buy, 3=Hold, 4=Sell, and 5=Strong Sell. We search public filings and other miscellaneous information available over the World Wide Web to identify security analysts that are subsequently appointed to the board of directors of the companies they follow. We start by identifying all analysts on the $\mathrm{I} / \mathrm{B} / \mathrm{E} / \mathrm{S}$ tape who provide at least one recommendation on a domestic stock between 1993 and 2006 . For each analyst, I/B/E/S provides a numeric identifier, the analyst's last name, the initial of his/her first name, and the analyst's brokerage house. Since our data construction methodology involves name searches, we delete observations with multiple names for a given analyst numeric identifier or multiple analyst and brokerage identifiers for a given name. Finally, we discard teams, as attribution of the recommendation is less clean in these cases.

We look at analysts exiting the industry during our sample period and generate an initial list of potential hires by matching the analyst's initials and last name to the names of all board members of all firms covered by the analyst during her tenure. For example if analyst J. Smith covered stock ABC and XYZ between 1994 and 1998 and exits the industry in 1998, we search the list of directors of ABC and XYZ for board members named J* SMITH appointed in or after 1998. Finally we hand-check each entry from this initial list in order to positively identify analysts appointed to the board of firms they used to cover. To do so, we search press releases regarding the appointment (which usually describe the board member's background and prior employment) and Zoominfo.com, a search engine that specializes in collecting and indexing biographical and employment data from publicly available documents over the Web. We also use a variety of other sources on a case-by-case basis, including contacting the company to confirm the identity and the background of the board 
member. We use a conservative approach and only retain entries for which we can positively identify the board member as a former security analyst from multiple sources.

We match our recommendation data to accounting and stock return data from CRSP/COMPUSTAT. We also utilize data on firm-level governance measures, drawn from the IRRC database available through WRDS.

Table I reports summary statistics for our sample. We can positively identify 51 unique situations where analysts exiting the industry are later appointed to the board of directors of a firm that they themselves previously covered. Collectively these analysts cover a total of 1,163 firms issuing 4,130 recommendations between 1993 and 2006. Our identification relies on the fact that these analysts cover a large number of stocks and produce numerous recommendations. Also, firms appointing former analysts to their board are covered by many other analysts: a total of 1,212 analysts making 4,716 recommendations on these firms. We therefore exploit variation within and across analysts to identify systematic differences in recommendations. Panels B, C, and D report board-, firm-, and analyst-level characteristics for our sample. Panels B and C reveal that firms that appoint analysts to the board are slightly larger than other firms and have a slightly higher percentage of independent directors, but these differences are not statistically significant. Panel D indicates that analysts who are appointed to the board tend to work for slightly larger brokerage houses and cover more stocks than other analysts, but again the differences are not significant.

Table II reports the distribution of our analyst appointments across industries The appointments are spread across a wide range of industries (29 of the Fama-French 49 industries), with the two largest appointment shares coming from Finance and Trading (10\%) and the Petroleum and Natural Gas industry (10\%). The total frequency (68) is greater than the total number of firm-appointments (51), as a number

of the firms switch industry classifications throughout our sample period. As we do analyses both pre- and post- appointment, we retain all industries that are represented.

\section{Bias in Appointed Recommendations}

\section{A. Distribution of recommendations}

The mere fact that analysts are subsequently appointed to boards of firms that Hiring Cheerleaders - Page 9 
they previously covered may not be unreasonable from a shareholder's perspective. Analysts spend years (and in some cases their entire careers) covering a small set of stocks, and so may be expected to have relative expertise on these firms. They may be the types of informed agents that shareholders would like as representatives on the board of directors. However, motivations based solely on this expertise carry no prediction on the level of recommendations. Actions based on window-dressing motives by firms, in contrast, do. In this section we examine the stock recommendations of analysts on firms that subsequently appoint them to their board of directors.

Table III presents the distribution of analysts' recommendations and tests the hypothesis that analysts hired by the firm they formerly covered issued more optimistic recommendations on these firms. Panel A reports the distribution of recommendations issued by analysts on firms who subsequently appoint them to the board of directors (i.e., if analyst Jim Smith covers firm XYZ and he is later hired by XYZ to serve on the board, we report the distribution of his recommendations on XYZ in Panel A). We refer to these as "Appointed recommendations."

We compare this distribution to three benchmarks. Panel B reports the distribution of all other recommendations on the $\mathrm{I} / \mathrm{B} / \mathrm{E} / \mathrm{S}$ tape. Panel $\mathrm{C}$ reports the distribution of recommendations by analysts who are not appointed to the board, on those same firms that do appoint an analyst to the board. (I.e. we report recommendations on XYZ by all other analysts, excluding the appointed analyst Jim Smith). Panel D reports the distribution of recommendation by analysts who are appointed to the board, on all the stocks they cover excluding the firm who appoints them to the board. (I.e. we report Jim Smith's recommendations on all other firms he covered, excluding the appointing firm XYZ).

Comparing Panel A and Panel B reveals that appointed recommendations are significantly more optimistic than the I/B/E/S population. Roughly $42 \%$ of recommendations issued by analysts subsequently hired by the firm they cover are Strong Buy recommendations compared with only $25 \%$ for the whole sample. Similarly, over $82 \%$ of appointed recommendations are buys (Buy or Strong Buy), compared with only $57 \%$ of all of the non-appointed recommendations; we are able to safely reject the null hypothesis of no difference between the two distribution (Chi-square statistic $=39.2$, 
p-value $<0.001)$. Panels $\mathrm{C}$ and $\mathrm{D}$ report very similar results in comparison to the Appointed recommendations of Panel A (Chi-square tests in both cases reject equal distributions with p-values $<0.001$ ). To summarize, we find that analysts hired by the firm they previously covered issue significantly more optimistic recommendations on these firms relative to: 1) the universe of all sell side analysts, 2) recommendations on all other firms that they themselves issue, 3) recommendations on the appointing firm issued by all other analysts.

\section{B. Regression results on the positive bias in board-appointed analyst recommendations}

In this section we run panel regressions on analyst recommendations to control for other determinants of recommendation levels. The dependent variable is the recommendation level of (1-5), which we reverse-score such that 1=Strong Sell, 2=Sell, $3=$ Hold, 4=Buy, and 5=Strong Buy. ${ }^{7}$ The key independent variable of interest is a categorical variable (Appointed Rec) that is equal to 1 if the recommendation is issued by an analyst who is subsequently appointed by the given firm as a board member, and 0 otherwise. A positive coefficient on this variable indicates that the appointed analyst issues more optimistic stock recommendations on the appointing firm relative to all other recommendations.

We include a number of firm-level controls: size, book-to-market, past 1-month, and past 1-year returns (from month t-12 to t-2). In addition, control variables for analyst and brokerage house include: two measure of analyst experience, the number of years an analyst has been issuing recommendations on $\mathrm{I} / \mathrm{B} / \mathrm{E} / \mathrm{S}$, and the number of years the analyst has been issuing recommendations on the given stock; an affiliation dummy, equal to one if the analyst is employed by a bank that has an underwriting relationship with the given firm; an All-Star dummy variable, equal to one if the analyst is listed as an "All-Star" in the October issue of Institutional Investor magazine in that year; ${ }^{8}$ a measure of brokerage size, equal to the total number of analysts employed by the brokerage house, a measure of if the analyst shares an alumni connection with any

\footnotetext{
${ }^{7}$ Note that on I/B/E/S, Strong Buys are coded equal to 1, and Strong Sells are coded equal to 5; we reverse this convention and set Strong Buys=5 and Strong Sell=1, and so on, such that increases in recommendation levels correspond to increases in optimism.

8 The list of affiliated analysts and all-star analysts are from Ljungqvist at al. (2006, 2007).
} 
of the senior officers in the firm (CEO, CFO, or Chairman of the Board) (see Cohen, Frazzini, and Malloy (2010)); and fixed effects for recommendation month, analyst, firm, and industry, where indicated. ${ }^{9} \quad$ Standard errors are clustered at the recommendation month level.

Table IV reports the regression results. Consistent with the results in Table III, in every specification the coefficient on Appointed Rec is positive and highly significant, indicating that the appointed recommendations are significantly more optimistic. The interpretation of the coefficient in the first column, equal to $0.48(t=5.90)$, is that analysts' recommendations are shifted half of a rating higher on firms that subsequently appoint them as board members; so while the mean rating is between a Buy and a Hold (3.74), the appointed analyst's recommendation rises to between a Strong Buy and a Buy (4.22) on firms to which he is subsequently appointed. The appointment effect is largely unaffected by other firm-level, analyst-level, and brokerage-level controls. The effect does not seem to be driven by a certain time period of overly positive recommendations (month fixed-effects), by recommendations in a specific industry (industry fixed-effects), by something specific about analysts appointed to boards (analyst fixed-effects), or by something specific about the firms that appoint covering analysts to their boards (firm fixed-effects). ${ }^{10}$ Finally, in the last column we run the same regression specification, but as an ordered logit, and find nearly identical results. ${ }^{11}$

To get an idea of the magnitude of the Appointed Rec effect, we compare it with a well-documented conflict of interest effect: underwriting affiliation of a given analyst's investment bank with the firm in question (Lin and McNichols (1998), Lin, McNichols, and O'Brien (2005)). This literature shows that analysts have positively biased recommendations on these affiliated firms to which their investment banks do business.

\footnotetext{
${ }^{9}$ We use a 48-industry classification from Ken French's website.

${ }^{10}$ Given that we include fixed effects in all the regressions, constants are not reported. We have also run all the tests in the paper clustering at the firm- or analyst-level. These results, which are very similar to those reported here, are available on request. For example, replicating the full specification of Table IV but adjusting the standard errors for clustering at the firm- (analyst-) level gives a t-stat on Appointed Rec of 2.57 (3.13), significant at the one-percent level. We have also included firm age (which is highly correlated with size) in the regressions as a robustness check, and the results are virtually identical in terms of magnitude and significance.

${ }^{11}$ When the coefficients are transformed back into marginal effects, the predicted appointment effect is 0.42. We only report one set of coefficients, while the coefficients in an ordered logit can theoretically change for each increment of the dependent variable (1 to 2, 2 to 3 , etc.). We have checked this, especially for Appointed Rec, and the coefficient estimates are nearly identical across the increments.
} 
We include this affiliation effect in the regressions (Columns 2-9), and find that affiliation does have a positive effect on recommendations. However, it has no impact on the appointment effect (Appointed Rec), and the affiliation effect magnitude is 3 to 4 times smaller than the appointment effect ( 0.11 to 0.14 vs. 0.36 to 0.44 ).

In Columns 6-9, we include a dummy variable (Connected to Firm) that is equal to one if the analyst is connected to a senior officer through a school alumni link to control for the possibility that social ties may be driving the bias in recommendations that we observe for appointed analysts. The coefficient on Appointed Rec is virtually unchanged, while the coefficient on Connected to Firm is small and insignificant. ${ }^{12}$

We also break up our sample and examine our main result both before and after Regulation Fair Disclosure (Reg FD). Columns 7 and 8 show that the coefficient on Appointed Rec is very similar both before and after Reg FD, suggesting that changes in the information environment that may have accompanied the imposition of this law had virtually no impact on the appointment effect that we document here.

\section{Performance of Appointed Analysts}

\section{A. Performance on the appointing firm}

In this section we explore appointed analyst predictive ability. Under the hypothesis that analysts are selected to serve on the board on the basis of their perceived ability, potential efficacy, and general understanding of the appointing firm, one might expect that appointed analysts would demonstrate higher predictive ability on their stock recommendations on the appointing firm. We run a variety of tests to examine this conjecture.

First, we run panel regressions where the dependent variable is a dummy variable (Wrong Bet) equal to one if the return in the year immediately following the analyst's recommendation is the opposite sign from that implied by the recommendation. For example, if the subsequent annual stock return is negative (positive) and the recommendation is a strong buy or buy (strong sell or sell), then the variable Wrong

\footnotetext{
${ }^{12}$ Cohen et al. (2010) find, as we do here, that the social ties have no effect on recommendation levels. Note that we are only able to match $20 \%$ of analysts' education data (roughly 80,000 recommendations versus the full sample of 400,000). Our power is thus slightly reduced in Columns 6-9 where connections are included, which explains the slightly smaller (though still significant) t-stats.
} 
Bet is set equal to one. ${ }^{13}$ On the right-hand side of these regressions we control for known determinants of stock returns such as size, book-to-market, past 1-month, and past 1-year returns (from month t-12 to t-2), as well as the complete set of analyst-level controls used in Table IV.

The first three columns of Table $\mathrm{V}$ indicate that appointed analysts' recommendations on appointing firms are incorrect significantly more often than the typical analyst recommendation. For example, the coefficient on Appointed Rec in Column 3 of $0.154(t=2.67)$ is positive and highly significant. As the mean for Wrong Bet across all analyst recommendations is approximately $26 \%$, the coefficient on Appointed Rec here of indicates that appointed analysts' calls on appointed firms are around $50 \%$ more likely to be incorrect than the typical analyst recommendation, controlling for firm- and analyst-level characteristics $(15.4 \% / 26 \%)$.

We also employ a similar set of tests for changes in recommendations. The changes we examine are upgrades from the consensus recommendation (Upgrade), and downgrades from the consensus recommendation (Downgrade). Here, Wrong Bet is defined such that if the subsequent annual stock return is negative (positive) and the recommendation is an upgrade (downgrade), then the variable Wrong Bet is set equal to one. Once again, the last three columns of Table V indicate that appointed analysts' upgrades and downgrades on appointing firms are wrong bets significantly more often than the typical recommendation change. ${ }^{14}$ In Column 6 , for instance, while the mean for Wrong Bet across all analyst recommendation changes is approximately $18 \%$, the coefficient on Appointed Rec here (0.165, $t=3.11)$ indicates that appointed analysts' calls on appointed firms are around $90 \%$ more likely to be incorrect than the typical analyst recommendation change $(16.5 \% / 18 \%)$.

\footnotetext{
${ }^{13}$ We have also run these regressions where Wrong Bet is defined relative to positive and negative 4factor alphas, rather than returns. For example, if an analyst recommends a strong buy and the stock experiences a negative alpha over the next year, then Wrong Bet would be equal to one. Not surprisingly, since we already control for the known determinants of returns on the right-hand side of these regressions, the results using alphas are virtually identical to those reported here; for example, the coefficient on Wrong Bet using alphas as the threshold variable in Table V column 1 is $0.183(t=3.46)$.

${ }^{14}$ Since appointed analysts issue very few holds, sells, and downgrades, the results here in Table $\mathrm{V}$ are driven largely by the large number of incorrect calls on buys and upgrades by appointed analysts; restricting our definition of Wrong Bet to include only the performance on buys and upgrades yields very similar results. We document a similar finding in Table VI below that appointed analyst underperformance is concentrated in buys/upgrades on appointing firms when we explore the magnitude of the returns following appointed recommendations.
} 
We then run another set of panel regressions where the dependent variable is the actual return to the recommendation in the year immediately following a recommendation, rather than the dummy variables designed to capture right or wrong bets used in Table V. The key variable of interest is an interaction term Appointed Rec ${ }^{*}$ Upgrade (Appointed Rec ${ }^{*}$ Downgrade), which equals 1 if the analyst recommending the stock in question is subsequently appointed to the board of directors of that firm, and the recommendation in question is an upgrade (downgrade) from consensus. ${ }^{15}$ Dummy variables for Appointed Rec and Upgrade (Downgrade) are also included. The rest of the independent variables are the same as those used in Table IV. Again, by controlling for firm size, book-to-market, and past year returns on the right-hand side, we control for the well-known determinants of firm-level expected returns.

Consistent with the prior results on wrong bets, Table VI indicates that appointed analysts exhibit poor performance on their recommendations on appointing firms. For example, the negative and significant coefficient on the interaction term in Column $1(-19.5 \%, t=2.35)$ implies that appointed analysts do much worse on their upgrades on appointed firms than on the rest of their recommendations. Further, Column 1 also shows that while the typical analyst upgrade earns $9.4 \%$ in the subsequent year, suggesting that upgrades in general are informative about future returns, appointing analysts' upgrades on appointing firms earn only an insignificant $3.1 \%(=-19.5 \%+9.4 \%+13.3 \%$, F-test $=0.67)$. Also, the fact that appointed analysts' upgrades perform significantly worse than the rest of their recommendations on these firms (which earn between $10.6 \%$ to $13.3 \%$ ) is particularly surprising, since upgrades from consensus are presumably a bullish indicator, while the rest of these recommendations consist of agreements with consensus and downgrades from consensus. Columns 4-6 reveal no significant differences between appointed analysts' downgrades on appointing firms and the rest of their recommendations; the interaction term Appointed Rec ${ }^{*}$ Downgrade is always insignificant, and is not consistent in sign. ${ }^{16}$

\footnotetext{
${ }^{15}$ We have experimented with different definitions of upgrades and downgrades, e.g. upgrades from an analyst's last recommendation rather than upgrades from consensus, and the results are similar to those reported here. We prefer changes from consensus, as consensus is a measure of industry-aggregated information sets of analysts covering the firm that are currently revealed to the market.

${ }^{16}$ The coefficient on Downgrade suggests that the typical analyst downgrade is uninformative for future returns. Untabulated statistics indicate that the typical analysts' downgrades are weakly informative at
} 
Importantly, for both upgrades and downgrades, we find no evidence that appointed analysts exhibit superior performance on their recommendations of appointing firms.

Overall, whether we look at the number of incorrect calls, whether we look at recommendation levels or changes, or whether we look at the actual returns earned following these recommendations, we find a similar pattern of relative underperformance by appointed analysts on the firms that appoint them. In fact, we cannot find anything in the track records of appointed analysts to suggest that these analysts would be particularly effective monitors of the firms that appoint them.

\section{B. Overall performance of appointed analysts}

One argument that could be made in response to the results above is that perhaps analysts are selected to serve on the board on the basis of their overall perceived ability, and not necessarily on their stock return performance on a single firm. Under this hypothesis, one might expect these analysts to outperform other analysts in a more general sense. To explore this idea, we examine the overall earnings forecasting ability $^{17}$ and the overall stock return forecasting ability of appointed analysts.

Our first tests examine overall earnings forecasting ability. From the point of view of a firm hiring an analyst to serve on its board, the predictions in terms of analyst ability would seemingly apply to earnings forecasting ability as well as stock return forecasting ability. To conduct these tests, we compute the identical score measure used in Hong and Kubik (2003) in order to rank analysts across all the firms they cover in a given year. Specifically, we rank each analyst on each firm based on their absolute forecast error, computed as the absolute difference between her forecast for firm $j$ in year $t$ and the actual EPS of the firm, scaled by the stock price. For each analyst, we choose her most recent earnings per share forecast of year-end earnings issued by analyst $i$ on firm $j$ between January 1st and July 1st of year $t$. As in Hong and Kubik (2003), we then transform these rankings into a score measure (Score_EPS) where an analyst with a rank of one in terms of the lowest absolute forecast error receives a 100,

shorter horizons. However, irrespective of horizon, we find no evidence that appointed analysts' downgrades (or upgrades) on appointing firms are informative for future returns.

${ }^{17} \mathrm{We}$ examine the earnings forecasts of appointed analysts specifically on the firms that subsequently appoint them to the boards of directors further in Section VII.

$$
\text { Hiring Cheerleaders - Page } 16
$$


while the least accurate analyst receives a score of 0 ; the median and mean score for a firm in a year is $50{ }^{18}$ This relative measure of earnings forecasting ability allows us to compare all analysts, regardless of coverage, on the same scale. We take the average of this score measure across all the firms an analyst covers in a given year. ${ }^{19}$ We then run panel regressions of these annual analyst-level score measures on the same set of control variables used in Tables IV-VI, except that these control variables are now averaged across all firms that an analyst covers in a given year. Thus, observations are at the analyst-year level. ${ }^{20}$

The first three columns of Table VII present the results from these tests. The coefficient on Appointed Analyst is strongly negative, indicating that appointed analysts perform worse overall on their earnings forecasts, across all the firms they cover, than other analysts. The mean of the left-hand side variable equals 50 by construction, so the magnitude of the coefficients in Column 1-3 implies that appointed analysts' earn a ranking that is approximately $7-11 \%$ worse than the average analyst ranking. Column 1's coefficient on Appointed Analyst of $-5.63(t=4.16)$, for instance, implies that appointed analysts earn an over 11\% worse ranking than the average analyst.

We adopt a similar analyst-level ranking procedure in order to compare the overall stock return forecasting ability of appointed analysts. To do so, we compute the variable Wrong Bet as in Table $\mathrm{V}$ for each recommendation for each analyst; in these tests Wrong Bet is set equal to one if the recommendation is an upgrade (downgrade) and the subsequent year's stock-level four-factor alpha is negative (positive). We then sum across each analyst for each year to compute each analyst's proportion of incorrect calls in a given year; we then rank analysts inversely by this proportion, and then transform these rankings into a score measure (Score_Rec) similar to the one described above. This variable Score_Rec again varies between 0 and 100, where the most accurate analyst (i.e., with a rank of 1 in terms of the lowest proportion of incorrect

\footnotetext{
${ }^{18}$ As in Hong and Kubik (2003), we compute this measure as: SCORE $E_{i, j, t}=100-\left[\left(\right.\right.$ Rank-1)$_{1} /($ Number of Analysts $\left.\left._{j, t}-1\right)\right]^{*} 100$.

19 Results are not sensitive to using multiple-year averages to compute annual analyst-level score measures.

${ }^{20}$ As we are now collapsing and evaluating at the analyst level, our Appointed Analyst variable will not change for a given analyst over time (the analyst either is, or is not, subsequently appointed to a board), so we cannot include analyst fixed effects (nor firm fixed effects, as everything is collapsed to the analyst level). We can, and do, include year fixed effects in the regressions (Time) and all standard errors are adjusted for clustering at the ranking year level.
} 
calls) receives a score of 100 , and the least accurate analyst receives a score of 0 ; the median and mean score for a firm in a year is 50 .

The last three columns of Table VII present the results from these tests. The coefficient on Appointed Analyst is again strongly negative, indicating that appointed analysts also perform worse overall on their entire set of recommendations relative to other analysts. The magnitude of the coefficient is similar to the coefficient on the earnings rankings, again implying that appointed analysts earn a ranking that is about 6-11\% lower than the average analyst ranking. The Column 4 coefficient on Appointed Analyst of $-5.28(t=3.81)$ implies that appointed analysts earn a recommendation ranking over $10 \%$ worse than the average analyst.

Taken together, the findings in Tables V-VII indicate that appointed analysts are not only poor relative performers on their stock recommendations on appointing firms, but are also poor relative performers in a much broader sense as well. Specifically, appointed analysts perform poorly on both their earnings forecasts and their stock recommendations, across the entire portfolio of firms that they cover.

\section{The Timing of Positive Recommendations}

In this section we examine the dynamics of appointed analysts' recommendations. Specifically, we identify situations where firms may find a positive recommendation especially advantageous, and examine the behavior of the appointed analysts versus all other analysts at these times. The three situations we examine are: i.) periods preceding large amounts of stock issuance by the firm, ii.) periods following especially high short interest in the firm, and iii.) periods where the last analyst's recommendation downgraded the stock from the consensus.

To examine the first two scenarios, we use the same framework as in Table IV: the dependent variable is the level of recommendation, and as before the variable Appointed Rec measures the recommendations of analysts on the firms that subsequently appoint them to the board. All of the control variables from Table IV are included (but unreported) in Table VIII. In addition to these variables we include the following dummy variables: Last Rec. Downgrade, which equals 1 when the prior recommendation by the last analyst was a downgrade from consensus; High Short 
Interest, which equals 1 if the firm had above median short interest level in the month prior to the recommendation being issued; and High Future Issuance, which is equal to 1 if the firm has above median stock issuance in the 6 months following the recommendation. The results are in Columns 1-3 of Table VIII. From Column 1, the average analyst's recommendation is significantly more negative following times of high short interest (i.e., the coefficient on high short interest is negative and significant). However, Column 2 shows that analysts who are subsequently appointed to boards of the firms they cover have the complete opposite behavior and issue significantly more positive recommendations following months of high short interest on these firms. From Column 3, these same analysts also issue especially positive forecasts when the appointing firm has a large amount of stock issuance in the near future. Specifically, the coefficients on [High Short*Appointed Rec] of $0.326(t=2.14)$ and on [High Issue ${ }^{*}$ Appointed Rec] of $0.303(t=2.19)$ imply that the appointed analysts issue recommendations roughly twice as upwardly biased at these times.

To test the effect following a downgrade by another analyst, we use a slightly different specification. In Columns 4 and 5 , the dependent variable is a categorical variable equal to 1 if the given recommendation is a downgrade from the current consensus estimate. While the average analyst downgrades $42 \%$ of the time, the coefficient on Appointed Rec in Column 4 of -0.17 ( $t=3.06)$ indicates that appointed analysts downgrade only $25 \%$ of the time, or about $40 \%$ less often $(17 \% / 42 \%)$ on firms to which they are subsequently appointed to the board. In Column 5, we see that consistent with prior findings on analyst herding, the average analyst is about $7 \%$ more likely to downgrade from consensus if the prior analyst downgraded. Analysts later appointed to boards again do the exact opposite: they are especially unlikely to downgrade the firms they are appointed to at exactly those times when the last analyst downgraded from the consensus. To get an idea of the magnitude of the difference in behavior, when the prior recommendation was a downgrade, the average analyst will downgrade roughly $49 \%$ of the time $(42 \%+7 \%)$, while analysts later appointed to the boards of firms will only downgrade these appointing firms roughly $21 \%$ of the time (42\%+7\%-2\%-26\%), making them roughly $60 \%$ less likely to downgrade.

All of these tests point to the same types of behaviors: not only do analysts who 
are subsequently appointed to boards of firms they cover have significantly more positive recommendations, but they have especially large positive biases at precisely those times likely to be most valuable to these firms.

\section{The Post-Appointment Behavior and Performance of Appointing Firms}

In this section we explore the impact of appointing a former analyst to the board. We focus on the behavior and performance of appointing firms in the period after the appointment of a former analyst. ${ }^{21}$

\section{A. Behavior and Performance of Appointing Firms in the Post-Appointment Period}

As noted earlier, appointing overly bullish analysts need not imply bad monitoring. It is possible that optimistic directors might facilitate productive cooperation and communication among board members, or have ideas on new strategies and directions for growth. On the other hand, if firms are simply hiring cheerleaders for the current management and board, we might expect these firms to engage in more potentially questionable activities for shareholders once having the cheerleader on the board. One of these questionable behaviors that is both well documented and established in the literature is earnings management. Specifically, we focus on the portion of earnings management that is discretionary, and that has been shown to have a positive short-term impact on a firm's stock price: discretionary accruals (Sloan (1996)).

In this section we use the actual appointment dates (given in Table II) to identify changes in behavior and valuation implications. ${ }^{22}$ We present the results from regressions that test whether firms change their behavior after appointing their former analyst in Panel A of Table IX. Specifically, we regress a firm's discretionary accruals ${ }^{23}$

\footnotetext{
${ }^{21}$ We have also examined the characteristics of appointing firms, and find that appointing firms have significantly weaker governance, as measured by the Gompers, Ishii, and Metrick (2003) index (e.g., regressions of the GIndex on Appointing Firm yield a positive and significant on Appointing Firm $(=0.284, t=4.05))$. These results are available on request.

${ }^{22}$ In the next section we address the endogeneity of these appointment dates using an instrument for appointment dates.

${ }^{23}$ Discretionary accruals are computed using the modified Jones model described in Dechow, Sloan, and Sweeney (1995), and are equal to the residuals from firm-level regressions of total accruals on nondiscretionary accruals (where non-discretionary accruals are equal to the change in sales minus the change
}

Hiring Cheerleaders - Page 20 
on After Appointment, a categorical variable equal to 1 if the former analyst is a board director, and zero otherwise. In these tests, we include only those firms that do appoint analysts as board members to isolate the pre- and post-appointment effect on their behavior (a total of 402 firm-year observations). In addition, we include year fixed effects and firm fixed effects, as we want to capture solely the marginal effect of having the former analyst on the board, within a given firm, and controlling for sample time trends. We also include a number of firm-level control variables, which given the firm and year fixed effects, can be interpreted as the effect of these variables after firm averages and time period trends have been removed. The most important control variable is Total Accruals. ${ }^{24}$ With total accruals included, the coefficient on After Appointment can be interpreted as follows: given the same level of actual accruals before and after appointment, how much more of the accruals are discretionary (earnings management) after the appointment.

The positive and significant coefficient on After Appointment $(=0.022, t=2.06)$ in Column 1 implies that firms have significantly higher discretionary accruals (do significantly more earnings management), once the former analyst joins the board. To get an idea of magnitude, the unconditional average of accruals in the sample is -0.01 (with a median of 0 ), while 0.022 represents a move to the 75 th percentile, so the entire upper-quartile spread. Controlling for the level of Total Accruals has no effect on the magnitude or significance of After Appointment (Column 3). In the model including all controls (even current year's earnings level), the estimated change in behavior even increases in point-estimate and significance level, with After Appointment having a coefficient of $0.030(t=2.51)$.

We also compute value-weighted calendar-time portfolio returns in order to assess the post-appointment performance of our sample of appointing firms. Our goal is to assess the valuation implications associated with the observed appointment and potential behavior changes. It could as easily be a signal of a firm characteristic that causes both the appointment of a former analyst and poor subsequent performance (e.g. poor governance). This endogeneity will be directly addressed in the next section. In

in receivables plus gross property, plant, and equipment, all scaled by last year's total assets); each firm must have a minimum of ten years of data to be included in these regressions

${ }^{24}$ Total Accruals are the total annual amount of accruals of the firm, calculated as in Healy (1985). 
either case, though, the action of appointing a former analyst (who was optimistic and a poor relative performer) to the firm's board of directors may be informative about the future of the firm itself. To perform our analysis we construct two portfolios (After Appointment and Non-Appointment), as well as for a spread portfolio (Spread) which goes long the After Appointment portfolio and short the Non-Appointment portfolio each month. Firms that appoint analysts to the board enter the After Appointment portfolio in the month following their appointment, and remain in the portfolio for a year; all other stocks are placed in the Non-Appointment portfolio. Each month we compute the value-weighted return on each portfolio. We require the After Appointment portfolio to contain at least 3 stocks in any given month, and thus use a sample period of February 1997 to December 2006. We also compute 3-factor (Fama and French (1996), 4-factor (Carhart (1997), and 5-factor (Pastor and Stambaugh (2003)) alphas on each of the portfolios.

Panel B of Table IX presents the average monthly value-weighted calendar-time portfolio returns on all three portfolios. Panel B illustrates that the magnitude of underperformance by appointing firms is large: the Spread portfolio earns -1.3\% per month in raw returns, and up to almost $-2.0 \%$ per month in abnormal returns; the 3 and 5 -factor specifications are significant at the $5 \%$ level, while the raw and 4 -factor specifications are significant at the $10 \%$ level. The entire spread in abnormal returns between the two portfolios is due to the underperformance of the After Appointment portfolio, as the Non-Appointment portfolio earns alphas of almost exactly zero. Thus, the post-appointment performance of our sample of appointing firms is poor.

\section{B. Instrumental Variables Regressions}

To overcome the potential endogeneity of analyst board appointments, and specifically the possibility that poor anticipated performance might lead to analyst appointments (and that increases in earnings management might reflect efforts to mitigate poor stock price performance that would have occurred whether the analyst appointment took place or not), we also instrument for the appointment of a cheerleader analyst. To be clear, the regressions in Panel A of Table IX on firm behavior include 
only firms that appoint analysts, and examine the changes in behavior of solely these firms pre- and post-appointment. Thus, the only way that an endogeneity concern could be driving the effects we document there is through a pure timing explanation. In other words, a firm could decide to appoint a former friendly analyst to the board at precisely the time when it foresees a future deterioration in performance and future need for earnings management. In this interpretation, the change in earnings management behavior we document is concurrent with, but not a result of, the analyst's appointment. As this explanation is plausible, in this section we specifically instrument for the timing of analyst board member appointments to get around the potential endogeneity problems regarding the interpretation of the changes in firm behavior in Table IX Panel A.

We do so by exploiting the post-Global Settlement time period when analysts were widely scrutinized and scorned and hence in low demand to serve as potential directors. We use this exogenous shock to the desirability/availability of analysts in the pool of potential directors as an instrument for the actual appointment of cheerleader analysts. $^{25}$ This shock involved penalties for conflicts of interest stemming from several brokerage houses' relationships with, and behavior toward, investment banking clients, and is thus plausibly exogenous to any given firm's accounting reporting decision regarding discretionary accrual behavior.

Our first-stage regression, shown in Column 1 of Panel A Table X, is a regression of actual analyst appointment months on a categorical variable Post-Global Settlement that is equal to 1 for those firm-months after the Global Settlement (April 2003-April 2005) and zero otherwise, plus the same control variables used in Table IX. We run this predictive regression in the symmetric four year-window pre- and post-Global Settlement (so April 2001 - April 2005). ${ }^{26}$ Column 1 confirms that this post-Global Settlement variable is a negative and significant predictor of analyst appointment dates $(-0.014,(t=2.57))$. Note that this regression, like those in Panel A of Table IX, uses

\footnotetext{
${ }^{25}$ See Guner, Malmendier and Tate (2008) for a similar instrumental variables approach that uses the banking crisis in the late 1970s and early 1980s to identify times when commercial bankers were perceived to be less suitable candidates for corporate board directorships.

${ }^{26}$ We have experimented with this window, using six-, eight-, and ten-year windows around the Global Settlement, and the results are very similar in significance, with slightly smaller, but similar magnitudes. These results are available on request. We choose to show the four-year window as it isolates the tightest band of negative sentiment around the Global Settlement.
} 
only those firms that appoint an analyst as a board member, since the potential endogeneity problem, as described above, concerns the timing of cheerleader appointment; we do address firm selection issues below in a matched sample framework. We use the predicted values of this first-stage regression as estimates of the probability that a firm will appoint a cheerleader in any given month; for each firm we then take the firm-month with the highest predicted probability of appointment, and use this as our instrumented appointment date. We then define the variable Instrumented After Appointment as a categorical variable equal to 1 for all firm-years after the firm has its highest predicted probability of appointment, and 0 otherwise.

We use these instrumented appointments to examine the pre- and postappointment effect on firm behavior, as in Table IX. Specifically, the second stage regression in Column 2 of Panel A Table $\mathrm{X}$ is a regression of discretionary accruals on the variable Instrumented After Appointment plus the same control variables used in Column 1. Column 2 shows that instrumented appointments are positive and significant predictors of increases in discretionary accruals. From Column 2, the positive and significant coefficient of $0.018(t=2.71)$ implies that firms have significantly higher discretionary accruals (do significantly more earnings management), once a former analyst is predicted to join the board. This instrumented coefficient is similar in magnitude, and more precisely estimated than that in Table IX.

As a falsification test for our instrumentation technique, we look at the exact same instrumented analyst board appointments, but instead examine their impact on non-discretionary accruals. Non-discretionary accruals are the portion of accruals that firms have no ability to manipulate to create a better reflection of current earnings. Thus, the appointment of an analyst should have no impact on the discretionary accruals of a firm. If, in contrast, our instrumented analyst appointments are simply picking up a spurious relationship with firm accruals, we would expect to see this exhibited in both the discretionary and non-discretionary portions. We therefore run the exact same regression as in Column 2, but with the dependent variable now being non-discretionary accruals. In contrast to discretionary accruals (earnings management), Column 3 illustrates that instrumented appointments do not predict any increases in non-discretionary accruals. 


\section{Matched Sample Approach}

To address the possibility that the particular types of firms that choose to appoint former analysts may be the types of firms that would engage in earnings management regardless of whether or not they appointed a former analyst, we also employ a matched sample approach. We construct our matched sample by matching appointing firms to other firms that in the year leading up to the appointments were: i.) in the same Fama-French 49 industry category, ii.) in the same size quintile, iii.) in the same book-to-market quintile, and iv.) in the same discretionary accruals quintile as the appointing firms; but who did not appoint a cheerleader in the year of a cheerleader appointment. Note that these tests are designed to examine the composition of firms appointing cheerleader analysts, as opposed to the timing of when appointing firms choose to appoint cheerleader analysts (which we examined in our IV tests above).

Column 4 of Table $\mathrm{X}$ repeats the same result shown in Column 6 of Panel A Table IX, which regresses discretionary accruals on the After Appointment variable described in Table IX for the sample of appointing firms. Column 5 of Table X runs the identical regression, but this time on our matched sample of non-appointing firms designed to mimic the characteristics of the appointing firms. Unlike the appointing firms, which engage in significantly more earnings management post-appointment, the matched firms with similar characteristics (including engaging in the same level of earnings management in the period pre-appointment) exhibit no change in their earnings management following these cheerleader appointments. ${ }^{27}$

${ }^{27}$ This result is robust to variations in the way we construct our matching sample. For example, matching in addition on prior stock return performance gives the same result.

Hiring Cheerleaders - Page 25 


\section{Discussion}

In this section we discuss the interpretation of our results in greater depth. In particular we focus on the distinction between optimism in general versus sympathy towards management, as well as the interplay between the supply and demand for biased analysts.

\section{A. Optimism Versus Sympathy Towards Management}

From a shareholder perspective, there is an important distinction between purely optimistic analysts versus those analysts that are specifically sympathetic (cheerleaders) to management, in terms of ability to perform their duty of monitoring management. Most of our evidence on analyst recommendations to this point is consistent with both possibilities (although the opportunistic timing of especially positive recommendations from Table VIII appears less supportive of unconditional optimism, and more supportive of an analyst sympathetic toward management). In addition, our IV evidence on increased earnings management behavior following appointment appears more consistent with a cheerleader for management. We provide two additional tests to help further distinguish between exactly which explanation (optimism toward firm vs. cheerleader toward management) better describes our appointed analysts.

The first test has to do with optimism in earnings forecasts. If the analyst were simply optimistic about the future prospects of the firm, we would expect to see this expressed in both positive views in recommendations and earnings forecasts. Contrast this with an analyst who is a cheerleader for management. Here we would expect to observe positively biased recommendations as these clearly benefit the firm (Womack (1996)). By contrast, the direction of the cheerleader's bias is much less clear with respect to earnings forecasts. There is some positive effect at the time of increasing a consensus estimate, however this effect is likely mitigated by the negative effect of making it more difficult for the firm to beat earnings consensus at the time of earnings announcement. Consistent with this conjecture, in unreported tests we find no evidence of appointed analyst optimism on one- and two-year earnings forecasts. ${ }^{28}$ The fact that

\footnotetext{
${ }^{28}$ For example, when we employ regressions using the identical specification as in Table IV, but replacing
} the dependent variable with one-year earnings forecast optimism (measured as: (forecast-actual)/actual),

Hiring Cheerleaders - Page 26 
we find little evidence of optimism in the earnings forecasts of appointed analysts helps to rule out the possibility that appointed analysts are simply optimistic about firm prospects, as opposed to behaving in a specific way that benefits the managers of the firm (i.e., sympathetic to management).

We provide additional evidence on this distinction between being optimistic per se versus being sympathetic towards management by exploring post-appointment CEO compensation. For example, analysts who are purely optimistic about a firm's prospects may be especially hard on managers who fail to operate the business at a level that meets analysts' expectations (note the poor post-appointment performance in Table IX). In contrast, cheerleaders for management are, by definition, beholden to the managers of the firm. Using the instrumental variables framework described in Section VI above, we test the idea that boards with former analysts behave differently towards the CEO in the post-appointment period. Specifically, Panel B of Table X repeats the instrumental variable regressions in Columns 1 and 2 of Panel A, except that the control variable for total accruals is removed in both stages, and the dependent variable in the second-stage regression in Column 2 is now total CEO compensation (the variable TDC2 as reported in the ExecuComp Database). Column 2 indicates that firms increase CEO compensation post-appointment of a former cheerleader analyst. The coefficient of 4554 $(t=1.85)$, represents an increase of roughly one-third of a standard deviation in total compensation.

\section{B. Supply and Demand for Biased Analysts}

On the firm side, the question remains as to why firms choose to appoint these particular analysts to serve on their board of directors. Even if the only willing supply consists of these biased, relatively poor-performing analysts, the firms are still making an active decision to appoint them. Thus while it is true that an optimistic analyst may simply be more likely to accept a board seat than an otherwise similar analyst, our results imply that firms are either appointing the wrong analysts, or that firms should simply demand zero analysts if the only willing supply consists of biased analysts. One

the coefficient on Appointing Forecast is nearly zero, 0.005 ( $t=0.13)$.

Hiring Cheerleaders - Page 27 
might still argue that even a biased (and poor performing) analyst may be better than the next best alternative director for the firm. However, our IV results on the increased levels of earnings management, our results on the poor performance following the former analyst appointment, and the fact that these appointments are concentrated in significantly more poorly governed firms suggest that the board appointments of the former analysts are not incredibly effective monitoring choices from the view of shareholder interests.

On the analyst side, a similar question arises as to why analysts would want to bias their recommendations given their incentives to produce accurate forecasts (see Stickel (1992) and Mikhail, Walther, and Willis (1999)). In this case, the poor overall relative performance of these appointed analysts suggests that these analysts are unlikely to reap the rewards of good performance, and hence the cost of biasing recommendations on a single firm is quite low.

\section{Conclusion}

This paper provides evidence that firms appoint independent directors who are overly sympathetic to management, while still technically independent according to regulatory definitions. We do so by exploiting a unique, hand-collected database of former sell-side analysts who are appointed to the boards of companies they previously covered; importantly, our data provides us with information on these directors' views regarding the firm prior to being appointed to the board. Our empirical strategy thus allows us to directly evaluate the objectivity and potential effectiveness of a class of independent directors based solely on their observable opinions about the firm in question. We use these analysts' track records to examine the roles of optimism and ability in the board appointment process. In doing so we find evidence that boards appoint overly optimistic analysts (i.e., cheerleaders for management) who exhibit little skill in evaluating the firm itself, or in evaluating firms in general. While the literature has explored measures of director relationships, this paper is the first to empirically document this phenomenon of firms actively appointing board cheerleaders. 
The magnitude of the optimistic bias is large: $82.0 \%$ of appointed recommendations are strong-buy/buy recommendations, compared to $56.9 \%$ for all other analyst recommendations. At the same time, board-appointed analysts exhibit poor relative performance on their recommendations on appointing firms. They also demonstrate poor overall relative performance on their stock recommendations and earnings forecasts across all the firms that they cover. Additionally, these appointed analysts appear to be especially optimistic at times that are most favorable to the appointing firms (e.g., prior to stock issuances). Lastly, we examine the behavior and stock return performance of these appointing firms following the analyst's appointment, and find that appointing firms significantly increase their earnings management activities, increase CEO compensation, and perform poorly in the post-appointment period.

We believe that our results, when taken as a whole, shed new light on the views and characteristics of independent directors, and of the firms who appoint them. Further, the post-appointment behavior of the appointing firms in our sample suggest that exploring the past track records and backgrounds of all board members (beyond simply independent vs. inside) may be a useful way to identify cross-sectional variation in firm governance quality. Before the question of whether independent boards benefit shareholders can be adequately addressed, more research is needed to determine the true nature of "independence" within corporate boards, which begins with an understanding of the true independence of directors. 


\section{References}

Adams, Renee and Daniel Ferreira, 2007, A theory of friendly boards, Journal of Finance 62, 217-250.

Ai, Chunrong, and Edward Norton, 2003, Interaction terms in logit and probit models, Economics Letters 80, 123-129.

Berle, Adolph A., and Gardiner C. Means, The Modern Corporation and Private Property, New York, NY: The Macmillan Company, 1932.

Bertrand, Marianne, and Antoinette Schoar, 2003, Managing with style: The effect of managers on corporate policy, Quarterly Journal of Economics 118, 1169-1208.

Bhagat, Sanjai and Bernard S. Black, 2002, The non-correlation between board independence and long-term firm performance, Journal of Corporation Law 27, 231-273.

Brickley, James A., James S. Linck, and Jeffrey L. Coles, 1999, What happens to CEOs after they retire? New evidence on career concerns, horizon problems, and CEO incentives, Journal of Financial Economics 52, 341-377.

Carhart, Mark M., 1997, On persistence in mutual fund performance, Journal of Finance $52,57-82$.

Coates, John C.., 2000, Takeover defenses in the shadow of the pill: a critique of the scientific evidence, Texas Law Review 79, 271-382.

Cohen, Lauren, Andrea Frazzini, and Christopher J. Malloy, 2010, Sell side school ties, Journal of Finance, forthcoming.

Dahya, Jay, and John J. McConnell, Board composition, corporate performance, and the Cadbury Committee Recommendation, Journal of Financial and Quantitative Analysis 42, 535-564.

Daines, Robert, and Michael Klausner, 2001, Do IPO charters maximize firm value? Antitakeover provisions in IPOs, Journal of Law, Economics, and Organization $17,83-120$.

Dechow, Patricia M., Richard G. Sloan, and Amy P. Sweeney, 1995, Detecting earnings management, The Accounting Review 70, 193-226.

DeFond, Mark L., Rebecca N. Hann, and Xuesong Hu, Does the market value financial experience on audit committees of boards of directors?, Journal of Accounting Research 43, 153-193.

Duchin, Ran, John G. Matsusaka, and Oguzhan Ozbas, 2008, When are outside directors effective?, Working paper, University of Southern California. 
Fama, Eugene F., and Kenneth R. French, 1996, Multifactor explanations of asset pricing anomalies, Journal of Finance 51, 55-84.

Fama, Eugene F., and Michael C. Jensen, 1983, Separation of ownership and control, Journal of Law and Economics 26, 301-325.

Fich, Eliezer M., 2005, Are some outside directors better than others? Evidence from director appointments by Fortune 1000 firms, Journal of Business 78, 1943-1972.

Fich, Eliezer M., and Anil Shivdasani, 2006, Are busy boards effective monitors? Journal of Finance 61, 689-724.

Fields, M. Andrew and Phyllis Y. Keys, 2003, The emergence of corporate governance from Wall St. to Main St.: Outside directors, board diversity, earnings management, and managerial incentives to bear risk," The Financial Review 38, 124 .

Gilson, Stuart, 1990, Bankruptcy, boards, banks, and blockholders: Evidence on changes in corporate ownership when firms default, Journal of Financial Economics 27, 355-387.

Gompers, Paul A., Joy L. Ishii, and Andrew Metrick, 2003, Corporate governance and equity prices, Quarterly Journal of Economics 118, 107-155.

Guner, A. Burak, Ulrike Malmendier, and Geoffrey Tate, 2008, Financial expertise of directors, Journal of Financial Economics 88, 323-354.

Harris, Milton and Artur Raviv, 2007, A theory of board control and size, Review of Financial Studies, forthcoming.

Healy, Paul M., 1985, The effect of bonus schemes on accounting decisions, Journal of Accounting and Economics 7, 85-107.

Hermalin, Benjamin E. and Michael S. Weisbach, 1998, Endogenously chosen boards of directors and their monitoring of the CEO, American Economic Review 88, 96118.

Hermalin, Benjamin E. and Michael S. Weisbach, 2003, Boards of directors as an endogenously determined institution: A survey of the economic literature, Economic Policy Review (Federal Reserve Board of New York), April 2003, 7-26.

Hong, Harrison, and Jeffrey D. Kubik, 2003, Analyzing the analysts: Career concerns and biased forecasts, Journal of Finance 58, 313-351.

Jensen, Michael C., 1993, The modern industrial revolution, exit, and the failure of internal control systems, Journal of Finance 48, 831-880. 
Kaplan, S., and D. Reishus, 1990, Outside directorships and corporate performance, Journal of Financial Economics 1990, 389-410.

Lee, Changmin, 2007, What's happened over the past 10 years to the selection of retired CEOs as board members?, Working paper, Indiana University.

Lin, Hsiou-wei and Maureen F. McNichols, 1998, Underwriting relationships, analysts' earnings forecasts and investment recommendations, Journal of Accounting and Economics 25, 101-127.

Lin, Hsiou-wei, Maureen F. McNichols, and Patricia O'Brien, 2005, Analyst impartiality and investment banking relationships, Journal of Accounting Research 43, 623650 .

Ljungqvist, Alexander, F. Marston and W.J. Wilhelm, 2006, Competing for Securities Underwriting Mandates: Banking Relationships and Analyst Recommendations, Journal of Finance 61, 301-340.

Ljungqvist, Alexander, F. Marston and W.J. Wilhelm, 2007, Scaling the Hierarchy: How and Why Investment Banks Compete for Syndicate Co-Management Appointments, Review of Financial Studies forthcoming.

Michaely, Roni, and Kent L. Womack, 1999, Conflict of interest and the credibility of underwriter analyst recommendations, Review of Financial Studies 12, 653-686.

Mikhail, Michael B., Beverly R. Walther, and Richard H. Willis, 1990, Does forecast accuracy matter to security analysts? Accounting Review 74, 185-200.

Raheja, Charu G., 2005, Determinants of board size and composition: A theory of corporate boards, Journal of Financial and Quantitative Analysis 40, 283-306.

Romano, Roberta, 2005, The Sarbanes-Oxley Act and the making of quack corporate governance," Yale Law Review 114, 1521-1611.

Sloan, Richard G., 1996, Do stock prices fully reflect information in accruals and cash flows about future earnings?, The Accounting Review 71, 289-315.

Stern, Ithai, and James D. Westphal, 2006, The other pathway to the boardroom: Interpersonal influence behavior as a substitute for elite credentials and majority status in obtaining board appointments. Administrative Science Quarterly, 51, 169-204.

Stickel, Scott E., 1992, Reputation and performance among security analysts, Journal of Finance 47, 1811-1836.

Womack, Kent, 1996, Do brokerage analysts' recommendations have investment value? Journal of Finance 51, 137-167. 
Yermack, David, 2006, Board members and company value," Financial Markets and Portfolio Management 20, 33-47. 


\section{Table I: Summary Statistics}

This table shows summary statistics for the sample of sell side analysts and their covered stocks between 1993 and 2006 . Panel A reports the composition of the sample. Panels B and C report board and firm-level characteristics for the sample of firms that subsequently appoint an analyst who used to cover them to the board of directors, and for the sample of all other firms ("Others"). Panel D reports analyst characteristics for the sample of analysts who are appointed to the board of a firm they previously covered, and for the sample of all other analysts ("Others"). Brokerage Size is the total number of analysts issuing recommendations at the given analyst s brokerage house. Experience measures an analyst's history of recommending stocks on I/B/E/S at the time of the recommendation, in years.

\section{Panel A: Sample Composition}

Number of firms covered by appointed analysts

Number of firms appointing analysts to the board 1,163

Number of analysts covering appointing firms

Panel B: Board Characteristics Sample of firms appointing an analyst to their board

Average size of board

6.34

6.55

Percentage of independent directors on board

0.57

0.49

Panel C: Firm Characteristics Sample of firms appointing an analyst to their board

Number of recommendations

4,716

416,226

Market value of equity percentile

Book-to-market percentile

0.34

0.39

12-month prior return percentile

0.56

0.54

Number of analysts covering stock

10.81

9.27

Panel D: Analyst Characteristics Sample of analysts
appointed to board of firm

they previously covered

Number of stocks covered

16.9

12.6

Brokerage size

60.4

57.5

Experience in years 


\section{Table II: Firm and Analyst Board Appointments}

This table shows the industry distribution of the firms that appoint their former sell side analysts to their board of directors. The total number is greater than 51 as a number of the firms switch industry classifications over the 14 year sample.

\begin{tabular}{lcc}
\hline \multicolumn{1}{c}{ Industry Distribution } & & \\
\hline Industry & Frequency & Percent \\
\hline Automobiles and Trucks & 1 & 1.47 \\
Banking & 3 & 4.41 \\
Business Services & 6 & 8.82 \\
Chemicals & 2 & 2.94 \\
Computer Software & 3 & 4.41 \\
Construction Materials & 1 & 1.47 \\
Electrical Equipment & 1 & 1.47 \\
Electronic Equipment & 1 & 1.47 \\
Entertainment and Theatre & 3 & 4.41 \\
Finance and Trading & 7 & 10.29 \\
Food Products & 2 & 2.94 \\
Healthcare Services & 1 & 1.47 \\
Household and Consumer Goods & 2 & 2.94 \\
Insurance & 1 & 1.47 \\
Iron and Steel Works & 2 & 2.94 \\
Machinery & 5 & 7.35 \\
Measuring and Control (Laboratory) Equipment & 2 & 2.94 \\
Medical Equipment & 1 & 1.47 \\
Non-Metallic and Industrial Metal Mining & 1 & 1.47 \\
Petroleum and Natural Gas & 7 & 10.29 \\
Pharmaceutical Products & 2 & 2.94 \\
Precious Metals & 1 & 1.47 \\
Printing and Publishing & 1 & 1.47 \\
Recreation and Toys & 1 & 1.47 \\
Restaurants, Hotels, Motels & 2 & 2.94 \\
Retail & 3 & 4.41 \\
Transportation & 1 & 1.47 \\
Utilities & 1 & 1.47 \\
Wholesale & 4 & 5.88 \\
\hline Total & 68 & 100 \\
\hline
\end{tabular}




\section{Table III: Recommendations of Analyst Appointees}

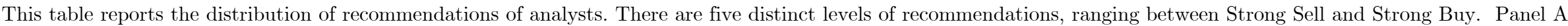

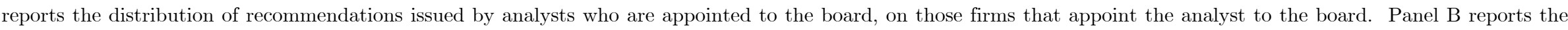

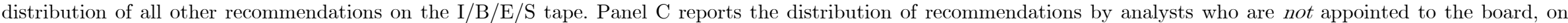

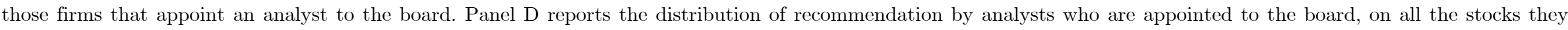

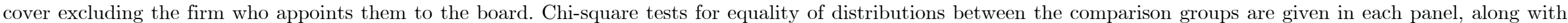
p-values.

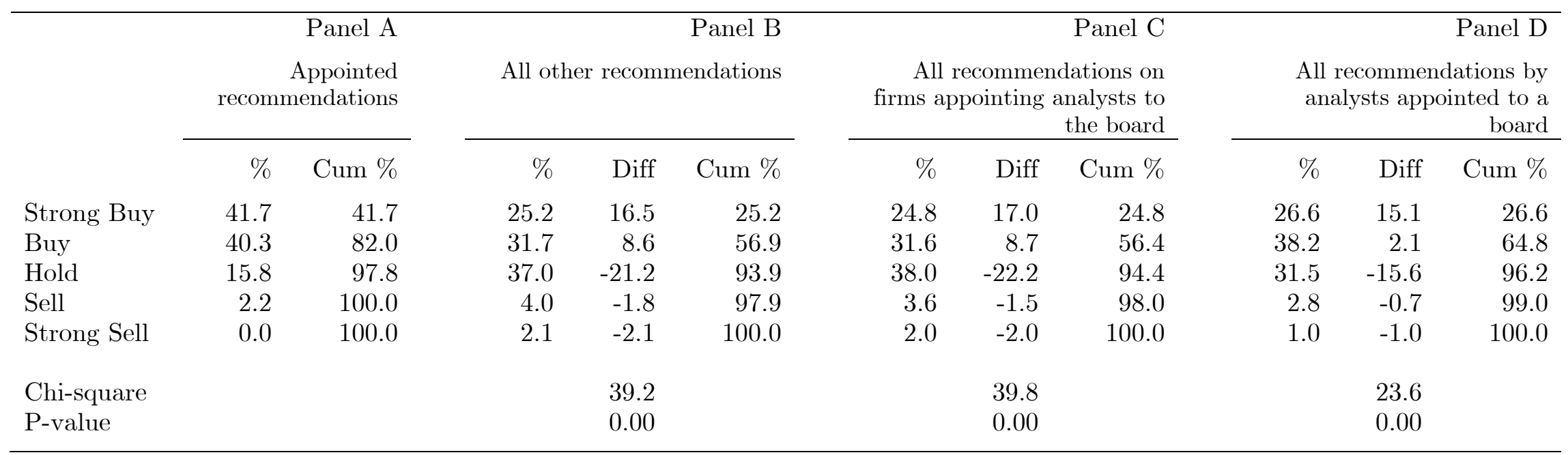




\section{Table IV: Appointed Analyst Recommendations}

The dependent variable in each regression is the level of recommendation, which ranges between 1 and 5 , and which we reverse-score such that $1=$ Strong Sell, $2=$ Sell, $3=$ Hold, $4=$ Buy, and $5=$ Strong Buy. The key variable of interest is in the first row: Appointed Rec equals 1 if the analyst recommending the stock in question is subsequently appointed to the board of directors of that firm, and 0 otherwise. The other independent variables are as follows: Size measures the log(ME) and $B / M$ measures the $\log (\mathrm{BE} / \mathrm{ME})$, of the firm being recommended. Past Month Return and Past Year Return measure the given stock's return in the prior month, and 11-months prior to that month respectively, from the recommendation date. Brokerage Size is the total number of analysts that work at the given analyst's brokerage house. At the time of each recommendation, Experience measures an analyst's history of recommending stocks on I/B/E/S (in years), while Exper. Rec. Firm measures the number of years an analyst has been recommending a given stock. All Star is a categorical variable equal to 1 if the analyst was voted an all star analyst in the October issue of Institutional Investor magazine for the given year. Connected to Firm is a categorical variable equal to 1 if the analyst attended the same school as one of the senior officers of the firm being recommended. Affiliation is a categorical variable that measures whether or not the given firm has an underwriting relationship with the analyst's brokerage. Column 7 and 8 split our sample period to pre- and post-Reg FD (October 2000). Column 9 runs an ordered logit regression, where the left hand side variable is the recommendation level (1-5). Fixed effects for recommendation month (Time), for industry (Industry) using the Fama-French industry definitions, for the firm (Firm), and for the analyst (Analyst), are included where indicated. All standard errors are adjusted for clustering at the recommendation month level, and t-stats using these clustered standard errors are included in parentheses below the coefficient estimates. $1 \%, 5 \%$, and $10 \%$ statistical significance are indicated with $* * *, * *$, and ${ }^{*}$, respectively.

(1)

\begin{tabular}{|c|c|c|c|c|c|c|c|c|c|}
\hline & (1) & (2) & (3) & (4) & $(5)$ & (6) & (7) & (8) & (9) \\
\hline & & & & & & & $\begin{array}{c}\text { Pre- } \\
\text { Reg FD }\end{array}$ & $\begin{array}{l}\text { Post- } \\
\text { Reg FD }\end{array}$ & Logit \\
\hline Appointed Rec & $\begin{array}{c}0.477^{* * *} \\
(5.90)\end{array}$ & $\begin{array}{c}0.420^{* * *} \\
(5.14)\end{array}$ & $\begin{array}{c}0.363^{* * *} \\
(4.70)\end{array}$ & $\begin{array}{c}0.435^{* * *} \\
(5.19)\end{array}$ & $\begin{array}{c}0.435^{* * *} \\
(5.14)\end{array}$ & $\begin{array}{c}0.417^{* * *} \\
(3.21)\end{array}$ & $\begin{array}{c}0.412^{* *} \\
(2.10)\end{array}$ & $\begin{array}{c}0.465^{* *} \\
(2.29)\end{array}$ & $\begin{array}{c}1.028^{* * *} \\
(4.16)\end{array}$ \\
\hline Size & & $\begin{array}{l}0.004 \\
(1.44)\end{array}$ & $\begin{array}{c}0.039^{* * *} \\
(12.54)\end{array}$ & $\begin{array}{c}0.008^{* * *} \\
(3.14)\end{array}$ & $\begin{array}{c}0.079^{* * *} \\
(8.13)\end{array}$ & $\begin{array}{c}0.092^{* * *} \\
(7.53)\end{array}$ & $\begin{array}{c}0.088 \\
(4.76)\end{array}$ & $\begin{array}{c}0.120^{* * *} \\
(6.83)\end{array}$ & $\begin{array}{c}0.020^{* *} \\
(2.39)\end{array}$ \\
\hline $\mathrm{B} / \mathrm{M}$ & & $\begin{array}{c}-0.037^{* * *} \\
(9.10)\end{array}$ & $\begin{array}{c}-0.017^{* * *} \\
(4.66)\end{array}$ & $\begin{array}{c}-0.027^{* * *} \\
(7.82)\end{array}$ & $\begin{array}{c}-0.022^{* * *} \\
(3.38)\end{array}$ & $\begin{array}{c}-0.006 \\
(0.57)\end{array}$ & $\begin{array}{c}-0.020 \\
(0.88)\end{array}$ & $\begin{array}{c}0.013 \\
(0.97)\end{array}$ & $\begin{array}{c}-0.120^{* * *} \\
(9.45)\end{array}$ \\
\hline Past Month Return & & $\begin{array}{c}0.224^{* * *} \\
(8.60)\end{array}$ & $\begin{array}{c}0.191^{* * *} \\
(8.50)\end{array}$ & $\begin{array}{c}0.221^{* * *} \\
(8.72)\end{array}$ & $\begin{array}{c}0.144^{* * *} \\
(6.50)\end{array}$ & $\begin{array}{c}0.116^{* * *} \\
(3.06)\end{array}$ & $\begin{array}{c}0.162^{* * *} \\
(2.83)\end{array}$ & $\begin{array}{c}0.008 \\
(0.16)\end{array}$ & $\begin{array}{c}0.283^{* * *} \\
(2.65)\end{array}$ \\
\hline Past Year Return & & $\begin{array}{c}0.121^{* * *} \\
(12.69)\end{array}$ & $\begin{array}{c}0.106^{* * *} \\
(12.77)\end{array}$ & $\begin{array}{c}0.119^{* * *} \\
(12.67)\end{array}$ & $\begin{array}{c}0.095^{* * *} \\
(12.29)\end{array}$ & $\begin{array}{c}0.082^{* * *} \\
(8.51)\end{array}$ & $\begin{array}{c}0.056^{* * *} \\
(4.03)\end{array}$ & $\begin{array}{c}0.089^{* * *} \\
(6.36)\end{array}$ & $\begin{array}{c}0.283^{* * *} \\
(11.25)\end{array}$ \\
\hline Brokerage Size & & $\begin{array}{c}-0.001^{* * *} \\
(6.93)\end{array}$ & $\begin{array}{c}-0.001^{* * *} \\
(4.43)\end{array}$ & $\begin{array}{c}-0.001^{* * *} \\
(6.94)\end{array}$ & $\begin{array}{c}-0.001^{* * *} \\
(6.33)\end{array}$ & $\begin{array}{c}-0.001^{* * *} \\
(8.23)\end{array}$ & $\begin{array}{c}0.000 \\
(0.29)\end{array}$ & $\begin{array}{c}-0.002^{* * *} \\
(8.55)\end{array}$ & $\begin{array}{c}-0.003^{* * *} \\
(8.78)\end{array}$ \\
\hline Experience & & $\begin{array}{c}0.004^{* * *} \\
(3.25)\end{array}$ & $\begin{array}{c}-0.024^{* * *} \\
(3.22)\end{array}$ & $\begin{array}{c}0.003^{* * *} \\
(2.84)\end{array}$ & $\begin{array}{c}0.002 \\
(1.63)\end{array}$ & $\begin{array}{c}0.002 \\
(1.04)\end{array}$ & $\begin{array}{c}-0.002 \\
(0.40)\end{array}$ & $\begin{array}{l}0.001 \\
(0.51)\end{array}$ & $\begin{array}{c}-0.008 \\
(1.60)\end{array}$ \\
\hline Exper. Rec. Firm & & $\begin{array}{c}-0.034^{* * *} \\
(13.55)\end{array}$ & $\begin{array}{c}-0.035^{* * *} \\
(15.44)\end{array}$ & $\begin{array}{c}-0.034^{* * *} \\
(14.08)\end{array}$ & $\begin{array}{c}-0.024^{* * *} \\
(9.41)\end{array}$ & $\begin{array}{c}-0.027^{* * *} \\
(6.25)\end{array}$ & $\begin{array}{c}-0.030^{* * *} \\
(3.61)\end{array}$ & $\begin{array}{c}-0.016^{* * *} \\
(3.41)\end{array}$ & $\begin{array}{c}-0.050^{* * *} \\
(6.45)\end{array}$ \\
\hline All Star & & $\begin{array}{c}-0.013 \\
(1.08)\end{array}$ & $\begin{array}{c}0.004 \\
(0.33)\end{array}$ & $\begin{array}{c}-0.012 \\
(0.94)\end{array}$ & $\begin{array}{c}-0.007 \\
(0.52)\end{array}$ & $\begin{array}{c}0.003 \\
(0.14)\end{array}$ & $\begin{array}{c}0.066^{* *} \\
(2.22)\end{array}$ & $\begin{array}{c}-0.084^{* * *} \\
(3.03)\end{array}$ & $\begin{array}{c}0.220^{* * *} \\
(4.44)\end{array}$ \\
\hline Connected to Firm & & & & & & $\begin{array}{c}-0.015 \\
(1.26)\end{array}$ & $\begin{array}{c}-0.025 \\
(1.16)\end{array}$ & $\begin{array}{c}-0.011 \\
(0.71)\end{array}$ & $\begin{array}{c}-0.001 \\
(0.04)\end{array}$ \\
\hline Affiliation & & $\begin{array}{c}0.136^{* * *} \\
(8.53)\end{array}$ & $\begin{array}{c}0.108^{* * *} \\
(6.50)\end{array}$ & $\begin{array}{c}0.129^{* * *} \\
(7.85)\end{array}$ & $\begin{array}{c}0.115^{* * *} \\
(6.56)\end{array}$ & $\begin{array}{c}0.115^{* * *} \\
(5.04)\end{array}$ & $\begin{array}{c}0.098^{* * *} \\
(3.09)\end{array}$ & $\begin{array}{c}0.137^{* * *} \\
(3.23)\end{array}$ & $\begin{array}{c}0.576^{* * *} \\
(10.59)\end{array}$ \\
\hline Fixed Effect & & Time & Time & Time & Time & Time & Time & Time & \\
\hline Fixed Effect & & & Analyst & Industry & Firm & Firm & Firm & Firm & \\
\hline
\end{tabular}




\section{Table V: Wrong Bets}

The dependent variable in each regression is Wrong Bet. Wrong Bet measures incorrect calls by analysts, and is a categorical variable equal to 1 if i.) the analyst recommends a Buy or Strong Buy on the given stock and the price decline over the following year or ii.) the analyst recommends a Sell or Strong Sell on the given stock and the price rises over the following year. It is defined equivalently in Columns 5-8 with the addition that the given recommendation is an upgrade or downgrade from the prevailing consensus recommendation, and then tracking subsequent performance of the stock. Appointed Rec equals 1 if the analyst recommending the stock in question is subsequently appointed to the board of directors of that firm, and 0 otherwise. The other independent variables are as follows: Size measures the $\log (\mathrm{ME})$ and $B / M$ measures the $\log (\mathrm{BE} / \mathrm{ME})$, of the firm being recommended. Past Month Return and Past Year Return measure the given stock's return in the prior month, and 11-months prior to that month respectively, from the recommendation date. Brokerage Size is the total number of analysts that work at the given analyst's brokerage house. At the time of each recommendation, Experience measures an analyst's history of recommending stocks on I/B/E/S (in years), while Exper. Rec. Firm measures the number of years an analyst has been recommending a given stock. All Star is a categorical variable equal to 1 if the analyst was voted an all star analyst in the October issue of Institutional Investor magazine for the given year. Connected to Firm is a categorical variable equal to 1 if the analyst attended the same school as one of the senior managers or board members of the recommended firm. Affiliation is a categorical variable that measures whether or not the given firm has an underwriting relationship with the analyst's brokerage. Fixed effects for recommendation month (Time), for the firm (Firm), and for the analyst (Analyst), are included where indicated. All standard errors are adjusted for clustering at the recommendation month level, and t-stats using these clustered standard errors are included in parentheses below the coefficient estimates. $1 \%, 5 \%$, and $10 \%$ statistical significance are indicated with $* * *, * *$, and $*$, respectively.

\begin{tabular}{|c|c|c|c|c|c|c|}
\hline & (1) & (2) & (3) & (4) & (5) & (6) \\
\hline & Rec & Rec & Rec & Up/Down & Up/Down & Up/Down \\
\hline Appointed Rec & $\begin{array}{c}0.123^{* *} \\
(2.52)\end{array}$ & $\begin{array}{c}0.172^{* * *} \\
(3.30)\end{array}$ & $\begin{array}{c}0.154^{* * *} \\
(2.67)\end{array}$ & $\begin{array}{c}0.148^{* * *} \\
(2.97)\end{array}$ & $\begin{array}{c}0.170^{* * *} \\
(3.64)\end{array}$ & $\begin{array}{c}0.165^{* * *} \\
(3.11)\end{array}$ \\
\hline Size & & & $\begin{array}{c}0.136^{* * *} \\
(16.87)\end{array}$ & & & $\begin{array}{c}0.064^{* * *} \\
(14.40)\end{array}$ \\
\hline $\mathrm{B} / \mathrm{M}$ & & & $\begin{array}{c}-0.020^{* * *} \\
(5.33)\end{array}$ & & & $\begin{array}{c}-0.002 \\
(0.51)\end{array}$ \\
\hline Past Month Return & & & $\begin{array}{c}0.018 \\
(0.99)\end{array}$ & & & $\begin{array}{c}0.029 * * \\
(2.20)\end{array}$ \\
\hline Past Year Return & & & $\begin{array}{c}0.023^{* * *} \\
(8.12)\end{array}$ & & & $\begin{array}{c}0.009^{* * *} \\
(4.30)\end{array}$ \\
\hline Brokerage Size & & & $\begin{array}{c}0.000^{* * *} \\
(3.30)\end{array}$ & & & $\begin{array}{c}0.000^{* * *} \\
(4.72)\end{array}$ \\
\hline Experience & & & $\begin{array}{c}-0.001 \\
(1.60)\end{array}$ & & & $\begin{array}{c}-0.002^{* * *} \\
(3.92)\end{array}$ \\
\hline Exper. Rec. Firm & & & $\begin{array}{c}-0.002 \\
(1.63)\end{array}$ & & & $\begin{array}{l}0.002 \\
(1.64)\end{array}$ \\
\hline All Star & & & $\begin{array}{c}0.014^{* * *} \\
(3.18)\end{array}$ & & & $\begin{array}{c}0.015^{* * *} \\
(2.89)\end{array}$ \\
\hline Affiliation & & & $\begin{array}{c}0.028^{*} \\
(1.69)\end{array}$ & & & $\begin{array}{c}0.021^{*} \\
(1.78)\end{array}$ \\
\hline Fixed Effect & Time & Time & Time & Time & Time & Time \\
\hline Fixed Effect & Analyst & Firm & Firm & Analyst & Firm & Firm \\
\hline
\end{tabular}




\section{Table VI: Appointed Analyst Recommendation Performance}

The dependent variable in each column is the one-year return following a recommendation change (Upgrade or Downgrade). In columns 1-3, the changes are upgrades from consensus (Upgrade), and in columns 4-6, the changes are downgrades from consensus (Downgrade). The key variable of interest is the interaction term in the first two rows: Appointed Rec ${ }^{*} U_{p g r a d e}$ (Downgrade), which equals 1 if the analyst recommending the stock in question is subsequently appointed to the board of directors of that firm, and the recommendation in question is an upgrade (or downgrade) from consensus. Dummy variables for Appointed Rec and Upgrade (Downgrade) are also included. The other independent variables are those used in Table IV, and are described there. Fixed effects for recommendation year (Time), and for the analyst (Analyst), are included where indicated. All standard errors are adjusted for clustering at the recommendation year level, and t-stats using these clustered standard errors are included in parentheses below the coefficient estimates. $1 \%$, 5\%, and $10 \%$ statistical significance are indicated with $* * *, * *$, and $*$, respectively.

\begin{tabular}{|c|c|c|c|c|c|c|}
\hline & (1) & $(2)$ & $(3)$ & (4) & $(5)$ & $(6)$ \\
\hline Appointed Rec*Upgrade & $\begin{array}{c}-0.195^{* *} \\
(2.35)\end{array}$ & $\begin{array}{c}-0.182^{* *} \\
(2.30)\end{array}$ & $\begin{array}{c}-0.146^{* *} \\
(2.05)\end{array}$ & & & \\
\hline Appointed Rec*Downgrade & & & & $\begin{array}{c}-0.038 \\
(0.50)\end{array}$ & $\begin{array}{c}0.050 \\
(0.57)\end{array}$ & $\begin{array}{l}0.063 \\
(0.67)\end{array}$ \\
\hline Upgrade & $\begin{array}{c}0.094^{* * *} \\
(3.12)\end{array}$ & $\begin{array}{c}0.073^{* * *} \\
(3.57)\end{array}$ & $\begin{array}{c}0.039 * * * \\
(2.97)\end{array}$ & & & \\
\hline Downgrade & & & & $\begin{array}{c}0.013 \\
(0.61)\end{array}$ & $\begin{array}{c}0.017 \\
(0.95)\end{array}$ & $\begin{array}{l}0.000 \\
(0.01)\end{array}$ \\
\hline Appointing Rec & $\begin{array}{c}0.133^{*} \\
(1.82)\end{array}$ & $\begin{array}{c}0.127^{* *} \\
(2.21)\end{array}$ & $\begin{array}{c}0.106^{*} \\
(1.86)\end{array}$ & $\begin{array}{c}0.014 \\
(0.22)\end{array}$ & $\begin{array}{c}0.016 \\
(0.35)\end{array}$ & $\begin{array}{l}0.017 \\
(0.35)\end{array}$ \\
\hline Size & $\begin{array}{c}0.015^{*} \\
(1.83)\end{array}$ & $\begin{array}{c}0.011 \\
(1.55)\end{array}$ & $\begin{array}{c}0.015^{* *} \\
(2.28)\end{array}$ & $\begin{array}{c}0.017^{* *} \\
(2.05)\end{array}$ & $\begin{array}{c}0.012^{*} \\
(1.67)\end{array}$ & $\begin{array}{c}0.016^{* *} \\
(2.35)\end{array}$ \\
\hline $\mathrm{B} / \mathrm{M}$ & $\begin{array}{c}0.076^{* *} \\
(2.47)\end{array}$ & $\begin{array}{c}0.074^{* * *} \\
(3.03)\end{array}$ & $\begin{array}{c}0.059^{* * *} \\
(2.78)\end{array}$ & $\begin{array}{c}0.079 * * \\
(2.49)\end{array}$ & $\begin{array}{c}0.076^{* * *} \\
(3.04)\end{array}$ & $\begin{array}{c}0.060^{* * *} \\
(2.81)\end{array}$ \\
\hline Past Month Return & $\begin{array}{c}0.000 \\
(1.33)\end{array}$ & $\begin{array}{c}-0.001^{* * *} \\
(3.75)\end{array}$ & $\begin{array}{c}0.000 \\
(1.32)\end{array}$ & $\begin{array}{c}0.000 \\
(1.43)\end{array}$ & $\begin{array}{c}-0.001^{* * *} \\
(3.77)\end{array}$ & $\begin{array}{c}0.000 \\
(1.32)\end{array}$ \\
\hline Past Year Return & $\begin{array}{c}-0.001 \\
(0.33)\end{array}$ & $\begin{array}{c}0.000 \\
(0.01)\end{array}$ & $\begin{array}{c}-0.011 \\
(1.70)\end{array}$ & $\begin{array}{c}-0.002 \\
(0.36)\end{array}$ & $\begin{array}{c}0.000 \\
(0.01)\end{array}$ & $\begin{array}{c}-0.012^{*} \\
(1.74)\end{array}$ \\
\hline Brokerage Size & $\begin{array}{c}0.012^{*} \\
(1.68)\end{array}$ & $\begin{array}{c}0.009^{*} \\
(1.69)\end{array}$ & $\begin{array}{c}0.006 \\
(1.23)\end{array}$ & $\begin{array}{c}0.013^{*} \\
(1.76)\end{array}$ & $\begin{array}{c}0.010^{*} \\
(1.77)\end{array}$ & $\begin{array}{c}0.006 \\
(1.31)\end{array}$ \\
\hline Experience & $\begin{array}{c}0.135^{* *} \\
(1.99)\end{array}$ & $\begin{array}{c}0.042 \\
(0.85)\end{array}$ & $\begin{array}{c}-0.004 \\
(0.07)\end{array}$ & $\begin{array}{c}0.135^{* *} \\
(1.97)\end{array}$ & $\begin{array}{c}0.042 \\
(0.84)\end{array}$ & $\begin{array}{c}-0.004 \\
(0.09)\end{array}$ \\
\hline Exper. Rec. Firm & $\begin{array}{c}0.011 \\
(0.11)\end{array}$ & $\begin{array}{c}-0.037 \\
(0.47)\end{array}$ & $\begin{array}{c}-0.053 \\
(0.77)\end{array}$ & $\begin{array}{c}0.005 \\
(0.06)\end{array}$ & $\begin{array}{c}-0.041 \\
(0.53)\end{array}$ & $\begin{array}{c}-0.055 \\
(0.82)\end{array}$ \\
\hline All Star & $\begin{array}{c}0.023 \\
(1.35)\end{array}$ & $\begin{array}{c}0.008 \\
(0.72)\end{array}$ & $\begin{array}{c}0.004 \\
(0.47)\end{array}$ & $\begin{array}{l}0.024 \\
(1.38)\end{array}$ & $\begin{array}{c}0.009 \\
(0.86)\end{array}$ & $\begin{array}{l}0.005 \\
(0.52)\end{array}$ \\
\hline Affiliation & $\begin{array}{c}-0.138^{* *} \\
(2.04)\end{array}$ & $\begin{array}{c}-0.177^{* *} \\
(2.82)\end{array}$ & $\begin{array}{c}-0.140^{* *} \\
(2.14)\end{array}$ & $\begin{array}{c}-0.141^{* *} \\
(2.08)\end{array}$ & $\begin{array}{c}-0.179^{* * *} \\
(2.85)\end{array}$ & $\begin{array}{c}-0.140^{* *} \\
(2.14)\end{array}$ \\
\hline Recommendation Level & $\begin{array}{c}-0.055^{* *} \\
(2.41)\end{array}$ & $\begin{array}{c}-0.042^{* *} \\
(2.35)\end{array}$ & $\begin{array}{c}-0.016 \\
(1.20)\end{array}$ & $\begin{array}{c}-0.016 \\
(1.54)\end{array}$ & $\begin{array}{c}-0.010 \\
(1.06)\end{array}$ & $\begin{array}{c}0.000 \\
(0.06)\end{array}$ \\
\hline Fixed Effect & & Analyst & Analyst & & Analyst & Analyst \\
\hline Fixed Effect & & & Time & & & Time \\
\hline
\end{tabular}




\section{Table VII: Analyst Ability Ranking}

The dependent variable is a measure of analyst's rank relative to the rest of her peer analysts. In all columns, this rank is normalized to between 1-100, with the higher ranks meaning better performance (with 100 being the top performer, 1 being the poorest). In Columns 1-3, analysts are ranked according to their earnings forecast ability following Hong and Kubik (2003). In Columns 4-6, analysts are ranked according to the predictive ability of their recommendations (upgrades and downgrades) for future returns, using the measure Wrong Bets as defined in Table IV. In both measures the rankings are averaged across all stocks an analyst issues forecasts (or recommendations) on in a given year, giving an analyst level ranking for that year. Thus, observations are at an analyst-year level, so that every analyst-year will represent one observation. Firm Level Recommendation (Average Rec) is the average level of an analyst's recommendations for a given year, which ranges between $1=$ Strong Sell and $5=$ Strong Buy. Affiliation is the average percentage of covered stocks with which the analyst's brokerage house has an underwriting relationship. All Star is the percentage of years that the analyst is an all star out of all the years the analyst is issuing forecasts (recommendations). The independent variables Experience, Exper Rec. Firm, Brokerage Size, Size, and B/M are described in Table IV, and are average across the analyst's covered firms and years in the sample. Fixed effects for year (Time) are included where indicated. All standard errors are adjusted for clustering at the ranking year level, and t-stats using these clustered standard errors are included in parentheses below the coefficient estimates. $1 \%, 5 \%$, and $10 \%$ statistical significance are indicated with $* * *, * *$, and *, respectively.

(1)

\section{Earnings}

$-5.625^{* * *}$

Average Rec

Num Analysts

All Star

Affiliation

Experience

Exper. Rec. Firm

Brokerage Size

Size

$\mathrm{B} / \mathrm{M}$
(3) Earnings

$-5.640 * * *$

$-3.8$

$(3.26)$

$3.658^{* * *}$

(9.12)

$-1.153^{* * *}$

$-2.401^{* * *}$

$-5.528$

$(0.86)$

$-0.414^{* * *}$

$-1.344^{* * * *}$

(4.35)

$0.012^{*}$

(1.80)

$8.339 * * *$

(12.95)

1.021

(1.52)
(5)

(6)
Recommend

$-5.279 * * *$

$-5.514^{* * *}$

(4.07)

$-3.014^{* *}$

0.153

(0.17)

$-0.428 * * *$

$-5.745 * * *$

7.309

(1.46)

$-0.741^{* * *}$

$-0.099$

(0.39)

$0.008^{* *}$

(1.95)

$-1.315^{* * *}$

$0.615^{*}$

(1.69) 


\section{Table VIII: Timing of Analysts' Positive Recommendations}

This table reports panel regressions of analyst recommendations. The dependent variable in columns 1-3 is the level of recommendation $(R e c)$, which ranges from $1=$ Strong Sell to $5=$ Strong Buy. In columns 4 and 5 , the dependent variable is Downgrade, which is a categorical variable equal to 1 if the recommendation is a downgrade from the current consensus, and 0 otherwise. The independent variable Appointed $R e c$ is a categorical variable that is equal to 1 if the analyst recommending the given stock is subsequently appointed to the board of directors of the firm, and 0 otherwise. Last Rec. Downgrade is equal to 1 if the last recommendation on the stock (before the given analyst's recommendation) was a downgrade, and 0 otherwise. High Short Interest is equal to 1 if short interest in the month prior to the given recommendation was higher than the median, and 0 otherwise. High Future Issuance is equal to 1 if the firm being recommended has higher than median issuance over the 6 months following recommendation, and 0 otherwise. Interaction effects are included where shown. Size, B/M, Past Month Return, Past Year Return, Brokerage Size, Experience, Exper. Rec. Firm, All Star, and Affiliation are also included as controls in every regression, and are described in Table IV. Fixed effects for recommendation month (Time) and the firm (Firm) are included where indicated. All standard errors are adjusted for clustering at the recommendation month level, and t-stats using these clustered standard errors are included in parentheses below the coefficient estimates. $1 \%, 5 \%$, and $10 \%$ statistical significance are indicated with $* * *, * *$, and $*$, respectively.

\begin{tabular}{|c|c|c|c|c|c|}
\hline & (1) & $(2)$ & $(3)$ & $(4)$ & $(5)$ \\
\hline & $\operatorname{Rec}$ & $\operatorname{Rec}$ & Rec & Downgrade & Downgrade \\
\hline Appointed Rec & $\begin{array}{c}0.378^{* * *} \\
(4.22)\end{array}$ & $\begin{array}{c}0.279 * * \\
(2.51)\end{array}$ & $\begin{array}{c}0.230^{*} \\
(1.73)\end{array}$ & $\begin{array}{c}-0.171^{* * * *} \\
(3.06)\end{array}$ & $\begin{array}{c}-0.023 \\
(0.31)\end{array}$ \\
\hline Last Rec. Downgrade & $\begin{array}{c}-0.064^{* * *} \\
(13.50)\end{array}$ & $\begin{array}{c}-0.064^{* * *} \\
(13.49)\end{array}$ & $\begin{array}{c}-0.064^{* * *} \\
(13.49)\end{array}$ & $\begin{array}{c}0.069 * * * \\
(19.24)\end{array}$ & $\begin{array}{c}0.069^{* * * *} \\
(19.25)\end{array}$ \\
\hline High Short Interest & $\begin{array}{c}-0.083^{* * *} \\
(14.11)\end{array}$ & $\begin{array}{c}-0.083^{* * *} \\
(14.12)\end{array}$ & $\begin{array}{c}-0.083^{* * *} \\
(14.11)\end{array}$ & $\begin{array}{c}0.027^{* * *} \\
(8.99)\end{array}$ & $\begin{array}{c}0.027^{* * *} \\
(8.99)\end{array}$ \\
\hline High Future Issuance & $\begin{array}{c}0.066^{* * *} \\
(15.06)\end{array}$ & $\begin{array}{c}0.066^{* * *} \\
(15.06)\end{array}$ & $\begin{array}{c}0.066^{* * *} \\
(15.05)\end{array}$ & $\begin{array}{c}-0.018^{* * *} \\
(7.50)\end{array}$ & $\begin{array}{c}-0.018^{* * *} \\
(7.50)\end{array}$ \\
\hline High Short*Appointed Rec & & $\begin{array}{c}0.326^{* *} \\
(2.14)\end{array}$ & & & \\
\hline High Issue*Appointed Rec & & & $\begin{array}{c}0.303^{* *} \\
(2.10)\end{array}$ & & \\
\hline Last Rec Down*Appointed Rec & & & & & $\begin{array}{c}-0.259^{* * *} \\
(2.90)\end{array}$ \\
\hline Fixed Effect & Time & Time & Time & Time & Time \\
\hline Fixed Effect & Firm & Firm & Firm & Firm & Firm \\
\hline
\end{tabular}




\section{Table IX: Firm Behavior and Performance, Post-Appointment}

Panel A reports regressions of discretionary accruals over our sample period, 1993-2006. Discretionary accruals are computed using the modified Jones model described in Dechow, Sloan, and Sweeney (1995), and are equal to the residuals from firmlevel regressions of total accruals on non-discretionary accruals (which are equal to the change in sales minus the change in receivables plus gross property, plant, and equipment, all scaled by last year's total assets). Total Accruals are the total annual amount of accruals of the firm, estimated as in Healy (1985). These regressions include only those firms that appoint an analyst as a board member (402 firm-year observations). The independent variable of interest is After Appointment, a categorical variable equal to 1 for those firm-years after the analyst has been appointed to the board, and zero otherwise. Size, B/M, Return Volatility, and Past Year Return are defined as in Table VIII. Earnings are measured as the current year's net income, before extraordinary items. Firm fixed effects (Firm) and year fixed effects (Time) are included where indicated. All standard errors are adjusted for clustering at the year level, and t-stats using these clustered standard errors are included in parentheses below the coefficient estimates. Panel B presents value-weighted calendar-time monthly portfolio returns for two portfolios (After Appointment and Non-Appointment), as well as for a spread portfolio (Spread) which goes long the After Appointment portfolio and short the Non-Appointment portfolio each month. Firms that appoint analysts to the board enter the After Appointment portfolio in the month following their appointment, and remain in the portfolio for a year; all other stocks are placed in the Non-Appointment portfolio. 3-factor (Fama and French (1996), 4-factor (Carhart (1997), and 5-factor (Pastor and Stambaugh (2003)) alphas are computed, and 1\%, 5\%, and 10\% statistical significance are indicated with $* * *, * *$, and $*$, respectively.

\begin{tabular}{|c|c|c|c|c|c|c|}
\hline \multicolumn{7}{|c|}{ Panel A: Discretionary Accruals Post-Appointment } \\
\hline \multirow[t]{2}{*}{ Dep Variable: } & \multicolumn{6}{|c|}{ Discretionary Accruals } \\
\hline & (1) & $(2)$ & $(3)$ & (4) & $(5)$ & (6) \\
\hline After Appointment & $\begin{array}{c}0.022^{* *} \\
(2.06)\end{array}$ & $\begin{array}{c}0.022^{* *} \\
(2.27)\end{array}$ & $\begin{array}{c}0.019^{* *} \\
(2.12)\end{array}$ & $\begin{array}{c}0.021^{* *} \\
(2.23)\end{array}$ & $\begin{array}{c}0.021^{* *} \\
(2.29)\end{array}$ & $\begin{array}{c}0.030^{* *} \\
(2.51)\end{array}$ \\
\hline Total Accruals & & $\begin{array}{c}0.206^{* *} \\
(2.58)\end{array}$ & $\begin{array}{c}0.202^{* *} \\
(2.63)\end{array}$ & $\begin{array}{c}0.266^{* *} \\
(2.16)\end{array}$ & $\begin{array}{c}0.266^{* *} \\
(2.13)\end{array}$ & $\begin{array}{c}0.265^{* *} \\
(2.09)\end{array}$ \\
\hline Size & & & $\begin{array}{c}-0.005 \\
(0.91)\end{array}$ & $\begin{array}{c}-0.003 \\
(0.53)\end{array}$ & $\begin{array}{c}-0.003 \\
(0.50)\end{array}$ & $\begin{array}{c}-0.002 \\
(0.28)\end{array}$ \\
\hline $\mathrm{B} / \mathrm{M}$ & & & $\begin{array}{c}0.000 \\
(0.02)\end{array}$ & $\begin{array}{c}0.002 \\
(0.26)\end{array}$ & $\begin{array}{l}0.002 \\
(0.33)\end{array}$ & $\begin{array}{c}0.005 \\
(0.68)\end{array}$ \\
\hline Return Volatility & & & & $\begin{array}{c}-0.109^{*} \\
(1.72)\end{array}$ & $\begin{array}{c}-0.109 * \\
(1.95)\end{array}$ & $\begin{array}{c}-0.157^{* * *} \\
(2.72)\end{array}$ \\
\hline Past Year Return & & & & & $\begin{array}{c}0.000 \\
(0.03)\end{array}$ & $\begin{array}{l}0.000 \\
(0.01)\end{array}$ \\
\hline Earnings & & & & & & $\begin{array}{c}0.000 \\
(0.30)\end{array}$ \\
\hline Fixed Effect & Time & Time & Time & Time & Time & Time \\
\hline Fixed Effect & Firm & Firm & Firm & Firm & Firm & Firm \\
\hline \multicolumn{7}{|c|}{ Panel B: Value-Weighted Calendar Time Monthly Portfolio Returns } \\
\hline & & $\begin{array}{l}\text { raw } \\
\text { returns }\end{array}$ & $\begin{array}{c}\text { 3-factor } \\
\text { alpha }\end{array}$ & & $\begin{array}{l}\text { ctor } \\
\text { pha }\end{array}$ & $\begin{array}{c}\text { 5-factor } \\
\text { alpha }\end{array}$ \\
\hline After Appointment & & $\begin{array}{c}-0.0052 \\
(0.60)\end{array}$ & $\begin{array}{c}-0.0177^{* *} \\
(2.08)\end{array}$ & $\begin{array}{r}-0.0 \\
(1\end{array}$ & $\begin{array}{l}161^{*} \\
89)\end{array}$ & $\begin{array}{c}-0.0198^{* *} \\
(2.21)\end{array}$ \\
\hline Non-Appointment & & $\begin{array}{c}.0079^{* *} \\
(1.96)\end{array}$ & $\begin{array}{c}0.0000 \\
(0.47)\end{array}$ & & $\begin{array}{l}000 \\
30)\end{array}$ & $\begin{array}{c}0.0000 \\
(0.63)\end{array}$ \\
\hline Spread & & $\begin{array}{c}-0.0130 * \\
(1.78)\end{array}$ & $\begin{array}{c}-0.0177^{* *} \\
(2.09)\end{array}$ & $\begin{array}{r}-0.0 \\
(1\end{array}$ & $\begin{array}{l}162^{*} \\
89)\end{array}$ & $\begin{array}{c}-0.0198^{* *} \\
(2.21)\end{array}$ \\
\hline
\end{tabular}




\section{Table X: Post-Appointment Behavior: Instrumental Variables and Matched Samples}

The first three columns of Panel A report results from two-stage least squares regressions that instrument for the appointment for a cheerleader. These regressions include only those firms that appoint an analyst as a board member. The first stage of this regression (Column 1) is a regression of actual appointment months (of cheerleader analysts) on a categorical variable Post-Global Settlement that is equal to 1 for those years directly after the Global Settlement (April 2003-April 2005), and zero otherwise, plus the same control variables used in Table IX. The firm-month with the maximum predicted value of appointment is then designated as the instrumented appointment date, and the variable Instrumented After Appointment is then a categorical variable equal to 1 for those firm-years after the instrumented appointment date. The second stage regression in Column 2 (Column 3) is a regression of discretionary accruals (non-discretionary accruals) on the variable Instrumented After Appointment plus the same control variables used in Column 1. Columns 4 and 5 of Panel A compare the results in Table IX to those obtained from a matched sample panel regression of discretionary accruals on the same After Appointment variable described in Table IX. Column 4 repeats the same result shown in Column 6 Panel A of Table IX which regresses discretionary accruals on the After Appointment variable described in Table IX for the sample of appointing firms; Column 5 runs the identical regression, but this time on a matched sample of firms designed to mimic the characteristics of the appointing firms. The matched sample is constructed by matching appointing firms to firms in the same Fama-French 49 industry category, same size quintile, same book-to-market quintile, and same discretionary accruals quintile, but who did *not* appoint a cheerleader in the year of a cheerleader appointment. Panel B repeats the instrumental variables regressions in Columns 1 and 2 of Panel $\mathrm{A}$, except that the control variable for total accruals is removed in both stages, and the dependent variable in the second-stage regression in Column 2 is now total CEO compensation (the variable TDC2 as reported in Execucomp). Firm fixed effects (Firm) and year fixed effects (Time) are included where indicated. All standard errors are adjusted for clustering at the year level (month level in Column 1), and tstats using these clustered standard errors are included in parentheses below the coefficient estimates.

\begin{tabular}{|c|c|c|c|c|c|}
\hline \multirow[b]{4}{*}{ Dependent Variable: } & \multicolumn{5}{|c|}{ Panel A: IV Accruals Behavior and Matched Sample } \\
\hline & \multicolumn{3}{|c|}{ IV Estimation } & \multicolumn{2}{|c|}{ Matched-Sample } \\
\hline & 1st Stage & 2nd Stage & 2nd Stage & $\begin{array}{c}\text { Our } \\
\text { Sample }\end{array}$ & $\begin{array}{l}\text { Matched } \\
\text { Sample }\end{array}$ \\
\hline & Appoint Date & Disc Accr & Non-Disc & Disc Accr & Disc Accr \\
\hline & (1) & $(2)$ & (3) & (4) & (5) \\
\hline Post-Global & $-0.014^{* * *}$ & & & & \\
\hline Instrumented After & & $0.018^{* * *}$ & -0.028 & & \\
\hline Appointment & & $(2.71)$ & $(0.94)$ & & \\
\hline After & & & & $0.030^{* *}$ & 0.003 \\
\hline Appointment & & & & $(2.51)$ & $(0.75)$ \\
\hline Controls & Yes & Yes & Yes & Yes & Yes \\
\hline Fixed Effect & & Time & Time & Time & Time \\
\hline Fixed Effect & Firm & Firm & Firm & Firm & Firm \\
\hline
\end{tabular}


Table X: Post-Appointment Behavior: Instrumental Variables and Matched Samples (Continued)

\begin{tabular}{lcc}
\hline \multicolumn{3}{c}{ Panel B: IV Compensation Behavior } \\
\hline \multirow{2}{*}{ Dependent Variable: } & 1st Stage & 2nd Stage \\
\cline { 2 - 3 } & Appoint Date & Compensation \\
Post-Global & $(1)$ & $(2)$ \\
Settlement & $-0.012^{* * *}$ & \\
& $(2.62)$ & \\
Instrumented After & & $4554^{*}$ \\
Appointment & & $(1.85)$ \\
Controls & & Yes \\
& & \\
Fixed Effect & & Time \\
Fixed Effect & & Firm \\
\hline
\end{tabular}

